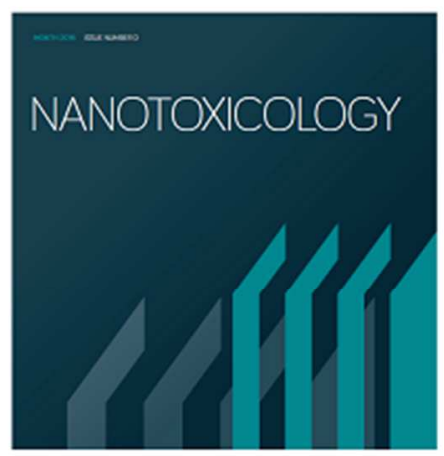

\title{
Nanosilver and the Microbiological Activity of the Particulate Solids versus the Leached Soluble Silver
}

\begin{tabular}{|c|c|}
\hline Journal: & Nanotoxicology \\
\hline Manuscript ID & TNAN-2017-0077.R1 \\
\hline Manuscript Type: & Short Communication \\
\hline Date Submitted by the Author: & 23-Nov-2017 \\
\hline Complete List of Authors: & $\begin{array}{l}\text { Faiz, Merisa; The University of New South Wales, School of Chemical } \\
\text { Engineering } \\
\text { Amal, Rose; The University of New South Wales, School of Chemical } \\
\text { Engineering } \\
\text { Marquis, Christopher; The University of New South Wales, School of } \\
\text { Biotechnology and Biomolecular Sciences } \\
\text { Harry, Elizabeth; University of Technology Sydney, ithree Institute } \\
\text { Sotiriou, Georgios; Karolinska Institutet, Department of Microbiology, } \\
\text { Tumor and Cell Biology } \\
\text { Rice, Scott; Nanyang Technological University, The Singapore Centre for } \\
\text { Environmental Life Sciences Engineering } \\
\text { Gunawan, Cindy; University of Technology Sydney, ithree Institute; The } \\
\text { University of New South Wales, School of Chemical Engineering }\end{array}$ \\
\hline Keywords: & $\begin{array}{l}\text { silver nanoparticles, Ag solids, silver leaching, toxicity, reactive oxygen } \\
\text { species }\end{array}$ \\
\hline Abstract: & $\begin{array}{l}\text { Nanosilver (Ag NPs) is currently one of the most commercialized } \\
\text { antimicrobial nanoparticles with as yet, still unresolved cytotoxicity origins. } \\
\text { To date, research efforts have mostly described the antimicrobial } \\
\text { contribution from the leaching of soluble silver, while the undissolved solid } \\
\text { Ag particulates are often considered as being microbiologically inert, } \\
\text { serving only as source of the cytotoxic Ag ions. Here, we show the rapid } \\
\text { stimulation of lethal cellular oxidative stress in bacteria by the presence of } \\
\text { the undissolved Ag particulates. The cytotoxicity characteristics are distinct } \\
\text { from those arising from the leached soluble Ag, the latter being locked in }\end{array}$ \\
\hline
\end{tabular}


organic complexes. The work also highlights the unique oxidative stressindependent bacterial toxicity of silver salt. Taken together, the findings advocate that future enquiries on the antimicrobial potency and also importantly, the environmental and clinical impact of Ag NPs use, should pay attention to the potential bacterial toxicological responses to the undissolved $\mathrm{Ag}$ particulates, rather than just to the leaching of soluble silver. The findings also put into question the common use of silver salt as model material for evaluating bacterial toxicity of Ag NPs.

\section{SCHOLARONE \\ Manuscripts}


${ }^{a}$ School of Chemical Engineering and ${ }^{b}$ School of Biotechnology and Biomolecular Sciences, Merisa B. Faiz ${ }^{\mathrm{a}}$, Rose Amal ${ }^{\mathrm{a}}$, Christopher P. Marquis ${ }^{\mathrm{b}}$, Elizabeth J. Harry ${ }^{\mathrm{c}}$, Georgios A. Sotiriou ${ }^{\mathrm{d}}$, Scott A. Rice ${ }^{\mathrm{e}}$, Cindy Gunawan ${ }^{\mathrm{a}, \mathrm{c}^{*}}$

\section{Nanosilver and the Microbiological Activity of the Particulate Solids versus the Leached Soluble Silver}

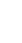

(1)

2

3

4

6


32 Nanosilver and the Microbiological Activity of the Particulate Solids versus

Word count: 6472

52

Keywords: silver nanoparticles; Ag solids; silver leaching; toxicity; reactive oxygen species

\begin{abstract}
Nanosilver (Ag NPs) is currently one of the most commercialized antimicrobial nanoparticles with as yet, still unresolved cytotoxicity origins. To date, research efforts have mostly described the antimicrobial contribution from the leaching of soluble silver, while the undissolved solid Ag particulates are often considered as being microbiologically inert, serving only as source of the cytotoxic Ag ions. Here, we show the rapid stimulation of lethal cellular oxidative stress in bacteria by the presence of the undissolved Ag particulates. The cytotoxicity characteristics are distinct from those arising from the leached soluble $\mathrm{Ag}$, the latter being locked in organic complexes. The work also highlights the unique oxidative stressindependent bacterial toxicity of silver salt. Taken together, the findings advocate that future enquiries on the antimicrobial potency and also importantly, the environmental and clinical impact of Ag NPs use, should pay attention to the potential bacterial toxicological responses to the undissolved Ag particulates, rather than just to the leaching of soluble silver. The findings also put into question the common use of silver salt as model material for evaluating bacterial toxicity of Ag NPs.
\end{abstract}




\section{Introduction}

59 The rapid development in nanotechnology has seen inorganic nanomaterials such as nanosilver,

60 copper oxide and zinc oxide, subjected to advanced physicochemical manipulation to exhibit

61 powerful antimicrobial activity (Gunawan et al. 2009, 2011, 2013a, Hajipour et al. 2012).

62 Among these materials, nanosilver (silver nanoparticles, Ag NPs) is currently one of the most

63 commercialized due to its potent and broad-spectrum antimicrobial characteristics (Consumer

64 Products Inventory - Project on Emerging Nanotechnologies). Along with applications as core or

65 co-antimicrobial ingredients in wound dressings and internal catheters (Ge et al. 2014), Ag NPs

66 have also been incorporated in an increasing array of consumer products (Deardorff 2014),

67 ranging from personal care products, textiles and household appliances to food and beverages

68 and even children's products (Benn et al. 2010, Quadros et al. 2013). The widespread use is

69 despite the ill-defined antimicrobial mechanisms of Ag NPs, in particular the lack of knowledge

70 regarding the origins of cytotoxicity. The controversy has been at least one of the underlying

71 reasons for regulatory bodies to still classify and regulate Ag NPs as regular bulk silver.

72 Therefore, the nanoparticles are subjected to the same reporting requirements, threshold levels

73 and toxicity tests as bulk silver, despite the mounting evidence indicating differences in their

74 antimicrobial potency and properties (Faunce and Watal 2010). The antimicrobial activity of Ag

75 NPs is influenced by the particles' physicochemical characteristics (e.g. size, shape, surface

76 functional groups) as well as interactions with the particles' environment. In real-world settings

77 of Ag NPs antimicrobial applications, the almost inevitable contact of the nanoparticles with

78 aqueous environments, including those in the environment and in the human body, will lead to

79 leaching of soluble silver species through oxidative dissolution of the silver metal (Trop et al.

80 2006, Benn and Westerhoff 2008, Liu et al. 2012, Sotiriou et al. 2012). Considerable research

81 efforts have described the cytotoxic activity of the leached soluble silver on bacteria, even in

82 their various forms, such as the soluble $\mathrm{Ag}(\mathrm{I})$-chloride anionic complexes (Levard et al. 2013)

83 and organo complexes (Gunawan et al. 2009), as a result of potential interactions of the released 
84 silver with the ubiquitous presence of halides $\left(\mathrm{Cl}^{-}, \mathrm{Br}^{-}, \mathrm{I}^{-}\right)$and biomolecules in the environment and in body fluids (Silver 2003, Liu et al. 2012, Eckhardt et al. 2013). Uncertainty however, still lingers as to the bacterial toxicological responses to the undissolved Ag residue (Gunawan et al. 2009, Sotiriou and Pratsinis 2010, Xiu et al. 2012), that remains after leaching of silver. The solid Ag particulates have been indicated to physically interact with cellular membranes of bacteria (Sondi and Salopek-Sondi 2004, Mirzajani et al. 2011), but otherwise are often regarded as being inert, indirectly contributing to the antimicrobial activity as a source of the cytotoxic $\mathrm{Ag}$ ions. This view is inclusive of the hypothesized Trojan-horse type of Ag NPs cytotoxicity, whereby leaching occurs intracellularly following uptake of particles, or, the suggested cellparticle contact to cause additional leaching at the cell-particle interface and in turn, increasing the uptake of Ag ions by bacteria (Lemire et al. 2013, Bondarenko et al. 2013). The elucidation of the source of Ag NPs cytotoxicity will not only clarify the nanoparticles' 'true' antimicrobial potency in real-world applications, but will also contribute to more accurate assessments of their long-term impact on the environment and human health.

Here, we investigated the origins of Ag NPs cytotoxicity through detailed investigations of bacterial toxicological responses to the 'overall' presence of nanosilver (i.e. both leached soluble $\mathrm{Ag}$ and $\mathrm{Ag}$ particulate residue are present in the systems), as compared to those of the corresponding pre-leached filtered Ag leachate samples. Nanosilver in products can be in the forms of nano-sized $\mathrm{Ag}(\mathrm{I})$ or metallic $\mathrm{Ag}^{0}$ coated on or impregnated in support materials (Gunawan et al. 2017). As model material, the current work used nanosilver in the form of nanosized $\mathrm{Ag}_{2} \mathrm{O}$ deposits $\left(\mathrm{d}_{T E M}=2 \mathrm{~nm}(\right.$ Gunawan et al. 2009)) homogenously dispersed on the surface of inert $\mathrm{TiO}_{2}$ support $\left(\mathrm{d}_{T E M}=30 \mathrm{~nm}\right.$ (Gunawan et al. 2009)). It is noteworthy to point out that studies have observed discrepancies on the leaching behaviour as well as capability of cellular oxidative stress stimulation of $\mathrm{Ag}(\mathrm{I})$ versus $\mathrm{Ag}^{0}$ nanoparticles (Gunawan et al. 2009, Gunawan et al. 2013b). Nonetheless, the generated knowledge of cellular responses to the two 
110 fundamental forms of nanosilver-derived microbiologically active components, that is, the

111 leached soluble silver and the solid Ag particulates in the present study, is relevant to the

112 countless nanosilver design with variation in the particle's properties (e.g. size, shape and

113 oxidation states). This facile approach enables unambiguous elucidation of the source of

114 nanoparticulate cytotoxicity without the need to employ simulation materials, such as soluble Ag

115 salt (Gunawan et al. 2009, Sotiriou and Pratsinis 2010, Gunawan et al. 2011, Bondarenko et al.

116 2013, Ivask et al. 2014), which, as also shown in the current work, exhibits different cytotoxicity

117 characteristics. We report cytotoxic activity of the solid Ag particulates on bacteria, distinct from

118 the leached soluble silver.

119

120 Methods

121 Synthesis of Ag NPs and Preparation of Ag leachate from NPs

122 The 5 at $\% \mathrm{Ag} / \mathrm{TiO}_{2}$ nanoparticles as finely dispersed $\mathrm{Ag}_{2} \mathrm{O}$ on inert $\mathrm{TiO}_{2}$ support were

123 synthesized using the flame spray pyrolysis (FSP) technique as earlier described (Gunawan et al.

$1242013 \mathrm{~b}$, note that at $\%$ refers to the percentage of $\mathrm{Ag}$ atom relative to the total number of atoms in

125 the particle). TEM images of the particles and XPS spectra that confirm the presence of silver (I)

126 oxide are available (Gunawan et al. 2009). The Ag-leachate was prepared by aseptically pre-

127 dissolving known amounts of $\operatorname{Ag}$ NPs $\left(3,6,8,10 \mathrm{mg} \mathrm{Ag} \mathrm{L}^{-1}\right)$ in sterile Luria Bertani (LB) broth

$128\left(5 \mathrm{~g} \mathrm{~L}^{-1}\right.$ yeast extract, $10 \mathrm{~g} \mathrm{~L}^{-1}$ tryptone, $5 \mathrm{~g} \mathrm{~L}^{-1} \mathrm{NaCl}$ in deionized water $)$ at $37^{\circ} \mathrm{C}, 280 \mathrm{rpm}$ under

129 dark conditions for $6 \mathrm{~h}$, unsonicated. The undissolved particulates (mean aggregate size $=1.09 \pm$

$130 \quad 0.03 \mu \mathrm{m}$ by dynamic light scattering (Gunawan et al. 2009)) were removed by centrifugation

$131(5,000 \mathrm{rpm})$ followed by filtration of the leachate with $0.22 \mu \mathrm{m}$ polyethersulfone membrane

132 (Millipore Express). Comparable light scattering intensity of the filtered Ag leachate to that of

133 the filtered LB medium confirmed the removal of the solid Ag residue (data not shown). The

134 concentration of soluble silver in the filtered Ag leachate was determined by inductively coupled 
135 plasma mass spectrometry (ICP-MS) (Nexion 300D, PerkinElmer). ICP-MS analysis was also

136 performed on the undissolved $\mathrm{Ag}$ residue (3-4 h digestion with $70 \%$ (v/v) $\mathrm{HNO}_{3}$ to dissolve the

137 Ag solid). This Ag solid concentration (no cells) reflected, at least in approximation, the

138 presence of the undissolved Ag fraction in the nanoparticle-bacteria exposure systems (note the

139 comparable leaching of Ag NPs in the presence and absence of bacteria, Figure 1 and S1,

140 Supplementary Data). The ICP-MS analysis of the (digested) solid Ag residue and the

141 corresponding Ag leachate fractions (undigested) found that their concentrations added up

142 (within 10-15\%) to the nominal total Ag concentrations of the nanoparticles (Figure S1). Finally,

143 the ICP-MS analysis of digested leachate samples found comparable Ag concentrations before

144 and after digestion, which further validated the removal of the solid Ag residue. Suspended

$145 \mathrm{Ag} / \mathrm{TiO}_{2}$ particulates in the growth medium is expressed as $\mathrm{mg} \mathrm{L}^{-1}$ to reflect their heterogeneous

146 presence, while the homogeneous nature of soluble $\mathrm{Ag}$ is referred to in $\mathrm{ppm}$.

148 Bacterial Growth Studies with $\mathrm{Ag} \mathrm{NPs,}$ Ag leachate and $\mathrm{AgNO}_{3}$ salt

149 The growth experiments on Bacillus subtilis strain UNSW 448700 were carried out in triplicate

150 in LB culture medium at $37^{\circ} \mathrm{C}, 280 \mathrm{rpm}$ under dark conditions for $6 \mathrm{~h}$. To prepare the bacterial

151 inoculum, a single agar plate colony was cultured overnight at $30^{\circ} \mathrm{C}, 220 \mathrm{rpm}$ in $\mathrm{LB}$ broth. A

152 measured volume of 1-2 $\mathrm{mL}$ of the overnight culture (typical $\mathrm{OD}_{600}$ of 6-8) was transferred into

$15350 \mathrm{~mL}$ fresh $\mathrm{LB}$ broth for a further $0.5-1 \mathrm{~h}$ conditioning at $37^{\circ} \mathrm{C}, 280 \mathrm{rpm}$. For the $\mathrm{Ag}$ NPs and

$154 \mathrm{AgNO}_{3}$ exposure, pre-weighed Ag NPs (1.1x of the intended dosage) and $0.5 \mathrm{~mL}(110 \mathrm{x}$

155 concentrated of the intended dosage) solution of $\mathrm{AgNO}_{3}$ were aseptically added into $50 \mathrm{~mL}$ and

$15649.5 \mathrm{~mL}$ LB respectively. The experiments were initiated by the addition of $5 \mathrm{~mL}$ bacterial

157 inoculum into the $50 \mathrm{~mL}$ broth containing suspended $\mathrm{Ag}$ NPs or dissolved silver salt $\left(\mathrm{OD}_{600}\right.$

158 bacteria initial $=0.04$, corresponding to $\sim 2 \times 10^{7} \mathrm{cfu} \mathrm{mL}^{-1}$ ). For the Ag leachate exposure, $5 \mathrm{~mL}$

159 of the bacterial inoculum was added into $50 \mathrm{~mL}$ LB containing 1.1x concentrated pre-leached Ag 
160 NPs (particle-free). The growth profiles were determined by $\mathrm{OD}_{600}$ measurement of the biomass

161 (UV/Vis spectrophotometer, Hitachi U-1100) and the growth inhibiting effects were assessed

162 relative to controls with no added silver. A cell-free silver control (particulates or soluble silver)

163 was employed as a reference to obtain the $\mathrm{OD}_{600}$ corresponding to the bacteria. The

164 corresponding leaching profile of Ag NPs during the bacterial exposure was measured by ICP-

165 MS (Nexion 300D, PerkinElmer). For this purpose, a measured volume was sampled from the

166 NPs-exposed culture, centrifuged $(5,000 \mathrm{rpm})$ then filtered with the $0.22 \mu \mathrm{m}$ membrane to

167 remove the bacteria and Ag solid. The resulting solution was 100x diluted in deionized water and

168 subjected to the ICP-MS analysis.

169

170

Detection of Intracellular ROS and Cell Viability

171 The measurement of cellular ROS generation was performed using the cell permeable oxidative

172 reporter dye $\mathrm{H}_{2}$ DCFDA (2', 7'-dichlorodihydrofluorescein diacetate, Sigma-Aldrich). Following

173 its uptake, cellular esterases cleave the diacetate moieties of $\mathrm{H}_{2}$ DCFDA to form $\mathrm{H}_{2} \mathrm{DCF}$, which

174 readily transforms to the fluorescent DCF when reacts with ROS. The cell viability assay was

175 based on the fluorescent nucleic acid dye propidium iodide (Sigma-Aldrich) staining. PI enters

176 cells with damaged cytoplasmic membrane, while being excluded by healthy cells. Following

177 removal of the culture medium by centrifugation, samples from the Ag NPs, Ag leachate and

$178 \mathrm{AgNO}_{3}$ exposure systems (and the silver-free controls) were washed and re-suspended in sterile

179 saline $\left(8 \mathrm{~g} \mathrm{~L}^{-1} \mathrm{NaCl}, 0.2 \mathrm{~g} \mathrm{~L}^{-1} \mathrm{KCl}\right)$ at $2.5 \times 10^{8} \mathrm{CFU} \mathrm{mL} \mathrm{m}^{-1}$. Independent cellular ROS and cell

180 viability assays were carried out with $10 \mu \mathrm{M} \mathrm{H} \mathrm{H}_{2}$ DCFDA and $30 \mu \mathrm{M}$ PI for $1 \mathrm{~h}$ and 15 min

181 respectively, at room temperature under dark conditions. The stained cells were washed with

182 saline and analysed by flow cytometry (FACSCanto ${ }^{\text {TM }}$ II, BD Bioscience) at $488 \mathrm{~nm}$ excitation

183 with $530 \mathrm{~nm}$ and $670 \mathrm{~nm}$ emission filter settings for the detection of DCF and PI fluorescence

184 respectively. DCF fluorescence was also measured using a microplate reader $\left(\right.$ Ensight $^{\mathrm{TM}}$

185 Multimode, Perkin Elmer) at $492 \mathrm{~nm}$ and $520 \mathrm{~nm}$ excitation and emission filter settings 
186 respectively. The stained cells were also visualized with a BX51WI fluorescence microscope

187 (Olympus) with 460-490 nm excitation filter settings.

188

189

\section{Results and discussion}

Bacterial growth inhibition: Activity of the solid Ag particulates, the leached soluble Ag and

silver salt

192 To distinguish the cytotoxicity or antimicrobial contribution of the leached soluble Ag and the

193 undissolved Ag particulates, we exposed a model bacteria B. subtilis UNSW 448700 to 0 - 10

$194 \mathrm{mg} \mathrm{Ag} \mathrm{L}{ }^{-1} \mathrm{NPs}\left(\mathrm{Ag} / \mathrm{TiO}_{2}\right)$ and compared the bacterial growth to that of the corresponding

195 leachate-only systems, as a function of soluble silver detected in the exposure systems. The

196 leachate samples were prepared by aseptically pre-dissolving Ag NPs in culture medium

197 followed by removal of the solid Ag residue. Firstly, as shown in Figure 1a, the dose-response

198 growth inhibiting effects of the Ag NPs correlates with the increasing concentration of soluble

199 silver that leached from the NPs. The extent of growth of B. subtilis was reduced to $\sim 80 \%$ upon

200 exposure to $3 \mathrm{mg} \mathrm{Ag} \mathrm{L}^{-1} \mathrm{NPs}$ (1.3 ppm silver leached into the culture medium at equilibrium)

201 relative to silver-free control cultures after $6 \mathrm{~h}$. The control cultures were characterized by a

202 relatively short lag phase of $1 \mathrm{~h}$, followed by 3 to $4 \mathrm{~h}$ active exponential growth phase before

203 entering the stationary phase at $6 \mathrm{~h}$ (Figure $1 \mathrm{~b}$ ). Increasing the NPs dosage to $6 \mathrm{mg} \mathrm{Ag} \mathrm{L} \mathrm{L}^{-1}(2.7$

204 ppm leached Ag) saw 50\% bacterial growth, while almost complete growth suppression was

205 observed at $\mathrm{MIC}_{95} 10 \mathrm{mg} \mathrm{Ag} \mathrm{L^{-1 }}$ NPs exposure (4 ppm leached Ag, see Figure $1 \mathrm{~b}$ for growth

206 profile, $\mathrm{MIC}_{95}$ is minimum inhibitory concentration that cause $5 \%$ growth relative to the control).

207 At all of the tested Ag NPs loading, leaching of Ag from NPs was rapid, with detection of $\sim 70 \%$

208 soluble $\mathrm{Ag}$ (relative to the leached $\mathrm{Ag}$ concentration detected at equilibrium) within 5 min of the

209 Ag NPs-bacterial exposure (see Figure 1c inset for leaching profile of $10 \mathrm{mg} \mathrm{Ag} \mathrm{L}^{-1} \mathrm{NPs}$ ).

210 Equilibrium was reached in $1 \mathrm{~h}$ with the soluble Ag concentration remained constant afterwards,

211 indicating absence of the Ostwald ripening phenomenon that refers to re-deposition of the 
212 leached Ag on larger particulates (Sotiriou et al. 2012). Increasing the Ag NPs loading saw

213 detection of elevated soluble Ag concentration at equilibrium, with the extent of leaching

214 essentially comparable at $38-40 \%$ relative to the total added Ag (Figure 1c). This is consistent

215 to earlier studies under comparable conditions (Gunawan et al. 2009, Sotiriou and Pratsinis

216 2010) with the relatively high degree of leaching was due to, at least in part, the presence of

217 organics in the culture medium as shown later in this study. Note that at all of the tested Ag NPs

218 loadings, similar extent of leaching were observed in the absence of bacteria, therefore excluding

219 the possibility of microbial-induced leaching of Ag (Figure S1).

220

221

222

comparison with bacterial growth in the corresponding leachate-only systems yields an

223

interesting observation. Exposure of B. subtilis to the pre-leached soluble Ag in fact resulted in

224 much less growth inhibition when compared to those of the corresponding Ag NPs samples

225 (Figure 1a). The presence of $\sim 1.3 \mathrm{ppm}$ Ag leachate for example, was benign to the cultures as

226 they grew to a similar extent as the silver-free control cultures after $6 \mathrm{~h}$. This was in contrast to

227 the $\sim 20 \%$ growth reduction of the bacteria when exposed to the corresponding $3 \mathrm{mg} \mathrm{Ag} \mathrm{L}^{-1} \mathrm{NPs}$

228 with comparable leached soluble Ag content. At higher exposure, the bacterial growth in $4 \mathrm{ppm}$

229 Ag leachate system was $\sim 85 \%$ relative to the control cultures (refer to Figure $1 \mathrm{~b}$ for growth

230 profile), in contrast to the near complete growth suppression observed in the corresponding 10

$231 \mathrm{mg} \mathrm{Ag} \mathrm{L^{-1 }}$ NPs system. Even doubling the concentration of Ag leachate to 8.3 ppm only slightly

232 reduced the bacterial growth to $\sim 75 \%$. The findings suggest predominant cytotoxicity

233 contribution from the undissolved Ag particulates, rather than that arising from the leached

234 soluble Ag. Further antimicrobial simulation with an equivalent concentration of soluble Ag

235 from $\mathrm{AgNO}_{3}$ salt as shown in Figure 1a, saw more severe growth inhibiting activity of the salt. In

236 the presence of 4 ppm soluble $\mathrm{Ag}$ from $\mathrm{AgNO}_{3}$ for example, $\sim 25 \%$ B. subtilis growth was 
237 observed relative to the control cultures after $6 \mathrm{~h}$ (growth profile is shown in Figure 1b), in

238 contrast to the $\sim 85 \%$ growth in the leachate system with comparable Ag concentration. Such

239 differences in cytotoxicity may arise from unique cellular physiological responses to the

240 different silver species; the leached soluble Ag and the undissolved Ag particulates from $\mathrm{Ag}$

241 NPs, and the soluble silver from silver salt, as investigated in the following.

242

243

244

245

246

247

\section{Dynamic stimulation of cellular oxidative stress and cell death}

We carried out dynamic tracking of intracellular reactive oxygen species (ROS) generation (measured by $\mathrm{H}_{2}$ DCFDA assay) and cell viability (measured by propidium iodide assay, whereby PI enters cells with damaged cytoplasmic membrane, which is indicative of cell death) over the $6 \mathrm{~h}$ growth course of $B$. subtilis in the presence of the various forms of silver; the Ag NPs (MIC $9510 \mathrm{mg} \mathrm{Ag} \mathrm{L}^{-1}$ as reference point, contained 4 ppm leached $\mathrm{Ag}$ ), its corresponding $\mathrm{Ag}$ leachate system (4 ppm $\mathrm{Ag}$ ) and the equivalent $\mathrm{AgNO}_{3}$ system (4 ppm $\mathrm{Ag}$ ).

\section{The solid Ag particulates and the leached soluble $\mathrm{Ag}$}

At 5 min exposure to $10 \mathrm{mg} \mathrm{Ag} \mathrm{L}^{-1} \mathrm{NPs}$, a 3-fold higher cellular ROS level was detected in $B$. subtilis relative to the basal ROS levels of the silver-free control cultures, which are by-products of aerobic metabolism in bacteria (Choi and Hu 2008, Gunawan et al. 2011, Eckhardt et al. 2013) (Figure 2a, 2b, 4a). Within 30 min of Ag NPs exposure, the cellular ROS level doubled to $\sim 6$-fold of the control. A secondary oxidative stress response, the cellular ROS stimulation has been increasingly realized as one of the major cellular toxicological responses to Ag NPs in bacteria (Choi and Hu 2008, Hwang et al. 2008, Lemire et al. 2013, Gunawan et al. 2013b). The ROS generation is thought to result from destruction of the iron-sulfur [4Fe-4S] clusters of proteins by Ag metal (Xu and Imlay 2012, Lemire et al. 2013) and in turn, releasing the Fentonactive free $\mathrm{Fe}$ into the cytoplasm for subsequent reaction with cellular $\mathrm{H}_{2} \mathrm{O}_{2}$ to produce hydroxyl 
262 radicals $\left(\mathrm{OH}^{\circ}\right)$ (Imlay et al. 1988). Alternatively, indirect destruction of the iron-sulfur clusters

263 could result from inhibition of respiratory enzymes by Ag NPs in bacteria (Li et al. 2010, 2011).

264 The resulting premature leakage of electrons to oxygen will generate superoxide radicals $\left(\mathrm{O}_{2}{ }^{\circ-}\right)$

265 (Imlay 2003) that in turn again, induces the release of free Fe from iron-sulfur clusters in

266 proteins (Kohanski et al. 2007). Indeed, there have been reports on the cytoplasmic presence of

267 the solid Ag particulates upon bacterial exposure to Ag NPs, as well as the presence of the solids

268 within the bacterial membrane layers (Morones et al. 2005, Grigor'eva et al. 2013, Pal et al.

269 2007). Here, 75-90\% PI-positive non-viable bacteria had been detected within 5 to 30 min

270 exposure to Ag NPs, then close to $100 \%$ bactericidal or cell death toxicity at as early as $1 \mathrm{~h}$

271 exposure (Figure 2a, 2b, 4b), which indicates cytoplasmic membrane as one of the target

272 destruction sites of the Ag NPs-stimulated cellular ROS (1-8\% non-viable cells were detected in

273 the control cultures over the $6 \mathrm{~h}$ growth course) (D'Autreaux et al. 2007, Lemire et al. 2013). As

274 expected, the levels of cellular ROS drastically dropped following the rapid high level

275 stimulation, with the majority if not all of the bacterial population were already killed (Sintubin

276 et al. 2011, Gunawan et al. 2013b). Up to this stage, the data suggest that the generation of high

277 levels of cellular ROS and associated bacteria killing was likely to be responsible for the near

278 complete suppression of $B$. subtilis growth (Figure 1a, 1b).

279

280

281

282

283

284

285

286

Interestingly, such cellular ROS stimulation was absent in the bacteria when studied in the corresponding $4 \mathrm{ppm} \mathrm{Ag} \mathrm{leachate} \mathrm{system.} \mathrm{Over} \mathrm{the} 6$ h growth course, only basal ROS levels, comparable to those of the silver-free control cultures were detected (Figure 2a, 3a, 4a) and not surprisingly, the little to no changes in the fraction of non-viable cells relative to the control (Figure 2a, 3a, 4b). The stimulation of lethal levels of cellular oxidative stress by the presence of solid Ag particulates therefore suggests their substantial contribution to the cytotoxicity effects observed in the growth studies. Recalling the observed $\sim 15 \%$ growth inhibition of the bacteria in 
287 the presence of 4 ppm Ag leachate (Figure 1a, 1b), it would be reasonable to deduce that the

288 exposure only resulted in sub-lethal cytotoxicity, causing a minor fraction of the viable cells

289 uncultivable or slowly proliferating, as further indicated by our growth prediction based on the

290 fraction of viable cells (Figure S2). Indeed, doubling the Ag leachate concentration to $8.3 \mathrm{ppm}$

291 still saw typical cellular ROS (Figure 3c, 4a inset) and dead cells (Figure 3c, 4b inset) detection

292 as those of the control cultures, despite the slightly higher growth suppression, at 25\% (Figure

293 1a).

294

295

The leached soluble Ag and silver salt

296 The minimal cellular ROS stimulation was also seen upon exposure of $B$. subtilis to the

297 equivalent 4 ppm soluble $\mathrm{Ag}$ from $\mathrm{AgNO}_{3}$. Similar to the $4 \mathrm{ppm}$ Ag leachate system, no elevated

298 level of cellular ROS was observed over the $6 \mathrm{~h}$ growth course relative to the control cultures

299 (Figure 2a, 3b, 4a). Unlike the leachate samples however, up to $40 \%$ non-viable cells were

300 detected in the salt system (Figure 3b, 4b), indicating attacks on cytoplasmic membrane

301 (Eckhardt et al. 2013). Considering the comparable Ag content, such discrepancies in

302 cytotoxicity are most likely to result from differences in the chemical speciation of the soluble

303 silver, as herein described. Our Ag NPs leaching study (at the MIC $9510 \mathrm{mg} \mathrm{Ag} \mathrm{L}^{-1} \mathrm{NPs}$ ) in the

304 individual culture medium components revealed a characteristic trend of complexation-assisted

305 dissolution of nanoparticles (Gunawan et al. 2011), with higher extent of Ag leaching in the

306 peptide-rich components, in particular tryptone (90\% leaching relative to the total added Ag),

307 compared to those in the deionized water (60\% leaching) or $\mathrm{NaCl}$ (10\% leaching) (Figure $4 \mathrm{c})$. A

308 soft Lewis acid, $\operatorname{Ag}(\mathrm{I})$ forms silver-peptide complexes upon its release from NPs (Bolea et al.

309 2014), which is most likely to result from its strong affinity to the $\mathrm{NH}_{\mathrm{x}}$ donor groups of histidine

$310\left(\mathrm{NH}^{+}\right)$, arginine $\left(-\mathrm{NH}_{2}{ }^{+}\right)$and lysine $\left(-\mathrm{NH}_{3}{ }^{+}\right)$amino acids and also to the thiol $\left(-\mathrm{S}^{-}\right)$donor groups

311 of cysteine and methionine amino acids (Eckhardt et al. 2013). Silver-peptide complexes also

312 form with $\mathrm{AgNO}_{3}$ (Bolea et al. 2014), with a fraction of silver is thought to remain as free ions in 
313 the organic-rich medium (Percival et al. 2005). Thermodynamically feasible, the co-existence of

314 free metal ions and organo metal complexes has been reported for the chemical speciation of

315 soluble copper salts, also a soft Lewis acid metal, in similar culture medium as that used here

316 (Gunawan et al. 2011) (note that the current technology for elemental analysis does not

317 differentiate free Ag ions to those locked in organo complexes (Eckhardt et al. 2013)). When

318 compared to free Ag ions, the hindered transport of the bulkier silver-peptide complexes into

319 bacteria (Solioz and Odermatt 1995) is thought to be at least in part, responsible for the

320 passivated, in this case, sub-lethal cytotoxicity of the Ag leachate. Unlike free Ag ions, research

321 indicates that soluble organo Ag complexes are not recognized by the P-type ATPase transporter

322 present in bacteria (Luoma 2008). As also observed in the current study with the $\mathrm{AgNO}_{3}$ systems,

323 exposure of bacteria to Ag ions has been reported to suppress their proliferation, which was

324 indicated to result from a ROS-independent inhibition of metabolic enzymes (dehydratases) (Xu

325 and Imlay 2012), the lack of cellular ROS stimulation also apparent in this work. Further,

326 complete suppression of $B$. subtilis growth was seen at $8.3 \mathrm{ppm} \mathrm{Ag}$ from $\mathrm{AgNO}_{3}$ (Figure 1a),

327 despite there being no change in the fraction of non-viable cells when compared to the $4 \mathrm{ppm} \mathrm{Ag}$

328 exposure (Figure $3 \mathrm{~d}, 4 \mathrm{~b}$ inset). Our growth prediction based on the fraction of viable cells

329 indicates major presence of non- or slowly proliferating viable cells with the $\mathrm{AgNO}_{3}$ exposure

330 (Figure S2). This loss in replication could also result from the known interactions of Ag ions

331 with DNA in bacteria (most likely with the phosphorus moieties) causing DNA condensation

332 (Feng et al. 2000). The seemingly higher cytotoxic effects of Ag ions as compared to the organo

333 Ag complexes are in agreement with other bacterial studies, whereby extracellular presence of

334 thiol-containing reduced gluthathione (GSH) as silver complexing agent lowered the

335 antimicrobial activity of Ag ions on the Gram-positive Staphylococcus aureus and the Gram-

336 negative Escherichia coli and Pseudomonas aeruginosa (Mulley et al. 2014). Finally, the

337 detection of only basal cellular ROS levels in the $\mathrm{AgNO}_{3}$ exposure systems, even at the double

$3388.3 \mathrm{ppm} \mathrm{Ag}$ (Figure 3d, 4a inset), rules out the oxidative stress stimulation as the main 
339 mechanisms of $\mathrm{AgNO}_{3}$ cytotoxicity. Indeed, studies have found no differences in the

340 antimicrobial activity of Ag ions under aerobic and anaerobic conditions on bacteria (Sintubin et

341 al. 2011).

342

\section{Conclusions}

344 Here, we report multiple cytotoxicity origins of Ag NPs towards bacteria. Presence of

345 undissolved Ag particulates in a biological environment is not inert. In their presence, rapid

346 generation of lethal cellular ROS levels were detected in bacteria, while the corresponding

347 leached soluble Ag, being locked in organo complexes, only imparts sub-lethal cytotoxicity. The

348 observed differences in bacterial toxicological responses to the solid versus soluble Ag

349 corroborate earlier reports on the distinct extent of growth inhibiting activity of the Ag NPs'

350 soluble and solid components (Gunawan et al. 2009, Sotiriou and Pratsinis 2010). With regard to

351 the widespread use of Ag NPs, the resolved unique toxicological responses are expected to result

352 in better recognition of the antimicrobial potency of the nanoparticles in real-world settings and

353 importantly, the long-term impact. Research inquiries have shown elevated and persistent

354 presence of silver in wounds, bladder and even in sewage and estuaries, being associated with

355 the intended or in some cases, accidental release from nanosilver applications; the use of wound

356 dressings, pesticides and washing machines are among the examples (Chen et al. 2004, Trop et al.

357 2006, Reidy et al. 2013, Donner et al. 2015, Beddow et al. 2017). The current findings imply

358 bacterial toxicological responses to not only the leached soluble Ag, but also the Ag particulates

359 in the microbial habitats. Indeed, studies have observed disruptions in the dynamic and balance

360 of microbial communities from natural aquatic waters upon exposure to nanosilver (Das et al.

361 2012, Beddow et al. 2017), with the work also detecting presence of soluble Ag and aggregates

362 of $\mathrm{Ag}$ from nanosilver in these environmental samples (Beddow et al. 2017). The resolved

363 toxicological responses is key to the elucidation of the recently discovered bacterial potential for

364 adaptation to Ag NPs cytotoxicity (Das et al. 2012, Gunawan et al. 2013b). Finally, the work 
365 highlights the unsuitability of soluble silver salt as model material for Ag NPs cytotoxicity in

366 biological environments, noting a distinct ROS-independent antimicrobial characteristic of

367 soluble $\mathrm{Ag}$ when supplied as $\mathrm{AgNO}_{3}$ salt.

368

369 Acknowledgments

370 This work was produced with the financial assistance of the Australian Research Council under

371 the ARC Australian Laureate Fellowship Program and the University of Technology Sydney

372 under the Chancellor's Postdoctoral Research Fellowship Program.

373

374 Declaration of interest

375 The authors declare no conflict of interest.

376

377

378

379

380

381

382

\section{References}

Beddow J, Stolpe B, Cole PA, Lead JR, Sapp M, Lyons BP, et al. 2017. Nanosilver inhibits nitrification and reduces ammoniaoxidising bacterial but not archaeal amo $A$ gene abundance in estuarine sediments. Environ Microbiol 19: 500-510.

Benn TM, Westerhoff P. 2008. Nanoparticle silver released into water from commercially available sock fabrics. Environ Sci Technol 42: 4133-4139.

384 Benn T, Cavanagh B, Hristovski K, Posner JD, Westerhoff P. 2010. The release of nanosilver

385 from consumer products used in the home. J Environ Qual 39: 1875-1882.

386 Bolea E, Jiménez-Lamana J, Laborda F, Abad-Álvaro I, Bladé C, Arola L, et al. 2014. Detection

387 and characterization of silver nanoparticles and dissolved species of silver in culture

388 medium and cells by AsFIFFF-UV-Vis-ICPMS: application to nanotoxicity tests. Analyst $389 \quad 139: 914-922$.

390 Bondarenko O, Ivask A, Käkinen A, Kurvet I, Kahru A. 2013. Particle-cell contact enhances

391 antibacterial activity of silver nanoparticles. PLoS One 8: e64060. 
392 Chen J, Han CM, Yu CH. 2004. Change in silver metabolism after the application of nanometer 393 silver on burn wound. Chin J Burns 20: 161-163.

394 Choi O, Hu Z. 2008. Size dependent and reactive oxygen species related nanosilver toxicity to $395 \quad$ nitrifying bacteria. Environ Sci Technol 42: 4583-4588.

396 Das P, Williams CJ, Fulthorpe RR, Hoque ME, Metcalfe CD, Xenopoulos MA. 2012. Changes

397 in bacterial community structure after exposure to silver nanoparticles in natural waters.

$398 \quad$ Environ Sci Technol 46: 9120-9128.

399 D'Autreaux B, Toledano MB. 2007. ROS as signalling molecules: mechanisms that generate $400 \quad$ specificity in ROS homeostasis. Nat Rev Mol Cell Biol 8: 813-824.

401 Deardorff J, 2014. Some antibacterials come with worrisome silver lining. Chicago Tribune, 16

402 Feb. Available from: http://articles.chicagotribune.com/2014-02-16/health/ct-nanosilver-

403 met-20140216_1_consumer-products-other-antibiotic-drugs-germs

404 Donner E, Scheckel K, Sekine R, Popelka-Filcoff RS, Bennett JW, Brunetti G, et al. 2015. Non-

405 labile silver species in biosolids remain stable throughout 50 years of weathering and 406 ageing. Environ Pollut 205: 78-86.

407 Eckhardt S, Brunetto PS, Gagnon J, Priebe M, Giese B, Fromm KM. 2013. Nanobio silver: its 408 interactions with peptides and bacteria, and its uses in medicine. Chem Rev 113: 4708$409 \quad 4754$.

410 Faunce T, Watal A. 2010. Nanosilver and global public health: international regulatory issues. $411 \quad$ Nanomedicine 5: 617-632.

412 Feng QL, Wu J, Chen GQ, Cui FZ, Kim TN, Kim JO. 2000. A mechanistic study of the 413 antibacterial effect of silver ions on Escherichia coli and Staphylococcus aureus. J Biomed $414 \quad$ Mater Res 52: 662-668.

415 Ge L, Li Q, Wang M, Ouyang J, Li X, Xing MMQ. 2014. Nanosilver particles in medical 416 applications: synthesis, performance, and Toxicity. Int J Nanomed 9: 2399-2407. 
418 Grigor'eva A, Saranina I, Tikunova N, Safonov A, Timoshenko N, Rebrov A, et al. 2013. Fine

419 mechanisms of the interaction of silver nanoparticles with the cells of Salmonella

420 typhimurium and Staphylococcus aureus. Biometals 26: 479-488.

421 Gunawan C, Teoh WY, Marquis CP, Lifia J, Amal R. 2009. Reversible antimicrobial

422 photoswitching in nanosilver. Small 5: 341-344.

423 Gunawan C, Teoh WY, Marquis CP, Amal R. 2011. Cytotoxicity origin of copper(II) oxide

424 nanoparticles: comparative studies with micron-sized particles, leachate, and metal Salts.

$425 \quad$ ACS Nano 5: 7214-7225.

426 Gunawan C, Teoh WY, Ricardo, Marquis CP, Amal R. 2013a. Zinc oxide nanoparticles induce

427 cell filamentation in Escherichia coli. Part Part Syst Charact 30: 375-380.

428 Gunawan C, Teoh WY, Marquis CP, Amal R. 2013b. Induced adaptation of Bacillus sp. to

429 antimicrobial nanosilver. Small 9: 3554-3560.

430 Gunawan C, Marquis CP, Amal R, Sotiriou GA, Rice SA, Harry EJ. 2017. Widespread and

431 indiscriminate nanosilver use: genuine potential for microbial resistance. ACS Nano 11:

$432 \quad 3438-3445$.

433 Hajipour MJ, Fromm KM, Ashkarran AA, Jimenez de Aberasturi D, de Larramendi IR, Rojo T, 434 et al. 2012. Antibacterial properties of nanoparticles. Trends Biotechnol 30: 499-511.

435 Hwang ET, Lee JH, Chae YJ, Kim YS, Kim BC, Sang BI, et al. 2008. Analysis of the toxic

436 mode of action of silver nanoparticles using stress-specific bioluminescent bacteria. Small

$437 \quad 4: 746-750$.

438 Imlay J, Chin S, Linn S. 1988. Toxic DNA damage by hydrogen peroxide through the Fenton

439 reaction in vitro and in vivo. Science 240: 640-642.

440 Imlay JA. 2003. Pathways of oxidative damage. Annu Rev Microbiol 57: 395-418.

441 Ivask A, Elbadawy A, Kaweeteerawat C, Boren D, Fischer H, Ji Z, et al. 2014. Toxicity

442 mechanisms in Escherichia coli vary for silver nanoparticles and differ from ionic silver.

$443 \quad$ ACS Nano 8: 374-386. 
444 Kohanski MA, Dwyer DJ, Hayete B, Lawrence CA, Collins JJ. 2007. A common mechanism of $445 \quad$ cellular death induced by bactericidal antibiotics. Cell 130: 797-810.

446 Lemire JA, Harrison JJ, Turner RJ. 2013. Antimicrobial activity of metals: mechanisms, 447 molecular targets and applications. Nat Rev Microbiol 11: 371-384.

448 Levard C, Mitra S, Yang T, Jew AD, Badireddy AR, Lowry GV, et al. 2013. Effect of chloride 449 on the dissolution rate of silver nanoparticles and toxicity to E. coli. Environ Sci Technol $450 \quad 47: 5738-5745$.

451 Li WR, Xie XB, Shi QS, Zeng HY, Ou-Yang YS, Chen YB. 2010. Antibacterial activity and 452 mechanism of silver nanoparticles on Escherichia coli. Appl Microbiol Biotechnol 85: $1115-1122$.

454 Li WR, Xie XB, Shi QS, Duan SS, Ou-Yang YS, Chen YB. 2011. Antibacterial effect of silver 455 nanoparticles on Staphylococcus aureus. Biometals 24: 135-141.

456 Liu J, Wang Z, Liu FD, Kane AB, Hurt RH. 2012. Chemical transformations of nanosilver in 457 biological environments. ACS Nano 6: 9887-9899.

458 Luoma SN, 2008. Silver nanotechnologies and the environment: old problems or new 459 challenges? The PEW Charitable Trusts. Available from: 460 https://www.nanotechproject.org/process/assets/files/7036/nano_pen_15 final.pdf $461 \quad$ [Accessed 11 December 2016]

462 Mirzajani F, Ghassempour A, Aliahmadi A, Esmaeili MA. 2011. Antibacterial effect of silver 463 nanoparticles on Staphylococcus aureus. Res Microbiol 162: 542-549.

464 Morones JR, Elechiguerra JL, Camacho A, Holt K, Kouri JB, Ramírez JT, et al. 2005. The 465 bactericidal effect of silver nanoparticles. Nanotechnology 16: 2346-2353.

466 Mulley G, Jenkins ATA, Waterfield NR. 2014. Inactivation of the antibacterial and cytotoxic 467 properties of silver ions by biologically relevant compounds. PLoS One 9: e94409. 
468 Pal S, Tak YK, Song JM. 2007. Does the antibacterial activity of silver nanoparticles depend on

469 the shape of the nanoparticle? A study of the Gram-negative bacterium Escherichia coli.

$470 \quad$ Appl Environ Microbiol 73: 1712-1720.

471 Percival SL, Bowler PG, Russell D. 2005. Bacterial resistance to silver in wound care. J Hosp $472 \quad$ Infect 60: 1-7.

473 Quadros ME, Pierson R, Tulve NS, Willis R, Rogers K, Thomas TA, et al. 2013. Release of 474 silver from nanotechnology-based consumer products for children. Environ Sci Technol $475 \quad 47: 8894-8901$.

476 Reidy B, Haase A, Luch A, Dawson KA, Lynch I. 2013. Mechanisms of silver nanoparticle 477 release, transformation and toxicity: a critical review of current knowledge and 478 recommendations for future studies and applications. Materials 6: 2295-2350.

479 Silver S. 2003. Bacterial silver resistance: molecular biology and uses and misuses of silver $480 \quad$ compounds. FEMS Microbiol Rev 27: 341-353.

481 Sintubin L, De Gusseme B, Van der Meeren P, Pycke BFG, Verstraete W, Boon N. 2011. The 482 antibacterial activity of biogenic silver and its mode of action. Appl Microbiol Biotechnol $483 \quad 91: 153-162$.

484 Solioz M, Odermatt A. 1995. Copper and silver transport by CopB-ATPase in membrane 485 vesicles of Enterococcus hirae. J Biol Chem 270: 9217-9221.

486 Sondi I, Salopek-Sondi B. 2004. Silver nanoparticles as antimicrobial agent: a case study on $E$. 487 coli as a model for Gram-negative bacteria. J Colloid Interface Sci 275: 177-182.

488 Sotiriou GA, Pratsinis SE. 2010.Antibacterial activity of nanosilver ions and particles. Environ $489 \quad$ Sci Technol 44: 5649-5654.

490 Sotiriou GA, Meyer A, Knijnenburg JTN, Panke S, Pratsinis SE. 2012. Quantifying the origin of 491 released $\mathrm{Ag}+$ ions from nanosilver. Langmuir 28: 15929-15936. 
492 Trop M, Novak M, Rodl S, Hellbom B, Kroell W, Goessler W. 2006. Silver-coated dressing

493 Acticoat caused raised liver enzymes and argyria-like symptoms in burn patient. J Trauma494 Injury Infect Crit Care 60: 648-652.

495

496

Xiu ZM, Zhang QB, Puppala HL, Colvin VL, Alvarez PJJ. 2012. Negligible particle-specific antibacterial activity of silver nanoparticles. Nano Lett 12: 4271-4275.

Xu FF, Imlay JA. 2012. Silver(I), mercury(II), cadmium(II), and zinc(II) target exposed enzymic iron-sulfur clusters when they toxify Escherichia coli. Appl Environ Microbiol 78: 36143621.

Consumer Products Inventory - Project on Emerging Nanotechnologies. Available from: http://www.nanotechproject.org/cpi [accessed 1 March 2017].

Supplementary material is available: Supplementary Figure S1, S2 and S3.

\section{Figure captions}

Figure 1. Bacterial growth in the presence of Ag NPs, Ag NPs leachate, silver salt and leaching of Ag NPs. (a) Growth of B. subtilis (6 h) relative to cell-only control upon exposure to Ag NPs (3, 6, 8, $\left.10 \mathrm{mg} \mathrm{Ag} \mathrm{L} \mathrm{L}^{-1}\right), \mathrm{Ag}$ leachate from $\mathrm{NPs}$ and $\mathrm{AgNO}_{3}$ as a function of soluble silver detected in the bacterial exposure systems (the growth studies were performed in LB medium). (b) Growth profiles of the bacteria in the presence of $10 \mathrm{mg} \mathrm{Ag} \mathrm{L}^{-1} \mathrm{NPs}$ (4 ppm Ag leached into medium at equilibrium), 4 ppm $\mathrm{Ag}$ leachate from NPs and $4 \mathrm{ppm} \mathrm{Ag}$ from $\mathrm{AgNO}_{3}$. Also shown is the cell-only control growth profile (dashed line). The growth in the presence of Ag was normalised to the extent of growth of the control (in colony forming units, cfu). (c) The corresponding equilibrium leaching of Ag NPs in the bacterial exposure systems, shown in the inset is the leaching profile for $10 \mathrm{mg} \mathrm{Ag} \mathrm{L}^{-1} \mathrm{NPs}$. Each data point in (a), (b), (c) is the average of triplicate experiments with error bars representing the maximum and minimum values detected. The growth studies were performed under dark conditions to render the $\mathrm{TiO}_{2}$ support 
518 photocatalytically inactive and the benign effect of the $\mathrm{TiO}_{2}$ support on B. subtilis growth had

519 been confirmed(Gunawan et al. 2013b). The growth studies were reproduced on different days

520 with unique bacterial inoculum and particle preparations.

521

522 Figure 2. Detection of cellular reactive oxygen species (ROS, $\mathrm{H}_{2} \mathrm{DCFDA}$ staining, green cells)

523 and cell death (PI staining, red cells) of B. subtilis over its growth course: (a) cell-only control

524 and (b) in the presence of $10 \mathrm{mg} \mathrm{Ag} \mathrm{L}^{-1} \mathrm{NPs}$. All stained samples were imaged at comparable

525 cell concentrations (scale bars $=50 \mu \mathrm{m}$ ).

526

527

528

529

530

531

532

533 Figure 4. (a) Dynamic stimulation of cellular ROS in $B$. subtilis measured by $\mathrm{H}_{2}$ DCFDA assay

534

535

536

537

538

539

540

541

542

543

Figure 3. Detection of cellular reactive oxygen species (ROS, $\mathrm{H}_{2}$ DCFDA staining, green cells) and cell death (PI staining, red cells) of B. subtilis over its growth course, in the presence of: (a) 4 ppm Ag leachate from NPs (equivalent leachate to $10 \mathrm{mg} \mathrm{Ag} \mathrm{L}^{-1} \mathrm{NPs}$ exposure), (b) $4 \mathrm{ppm} \mathrm{Ag}$ from $\mathrm{AgNO}_{3}$, (c) 8.3 ppm Ag leachate from NPs and (d) $8.3 \mathrm{ppm} \mathrm{Ag}$ from $\mathrm{AgNO}_{3}$. All stained samples were imaged at comparable cell concentrations (scale bars $=50 \mu \mathrm{m})$. over its growth course $(5,30 \mathrm{~min}$ and $1,3,4.5,6 \mathrm{~h})$ upon exposure to $10 \mathrm{mg} \mathrm{Ag} \mathrm{L}^{-1} \mathrm{NPs}$ (4 ppm Ag leached into medium at equilibrium), 4 ppm Ag leachate from NPs and 4 ppm Ag from $\mathrm{AgNO}_{3}$. The detected cellular ROS was normalised to the basal ROS levels of the cell-only control growth. Shown in the inset is cellular ROS detected in the presence of $8.3 \mathrm{ppm} \mathrm{Ag}$ leachate from NPs and $8.3 \mathrm{ppm} \mathrm{Ag}$ from $\mathrm{AgNO}_{3}$. (b) The corresponding dynamic cell death detection probed by PI staining of $B$. subtilis throughout its growth course. Also shown is the fraction of dead cells detected for the cell-only control. Statistical analysis of the data was performed with one-way ANOVA followed by Dunnett's posthoc analysis in Prism (GraphPad)

(Figure S3). The experiments in (a) and (b) were reproduced on different days with unique bacterial inoculum and particle preparations. (c) Leaching profile of $10 \mathrm{mg} \mathrm{Ag} \mathrm{L}^{-1} \mathrm{NPs}$ in cell- 
544 free individual components of the Luria Bertani (LB) culture medium $\left(5 \mathrm{~g} \mathrm{~L}^{-1} \mathrm{NaCl}, 5 \mathrm{~g} \mathrm{~L}^{-1}\right.$ yeast 545 extract, $10 \mathrm{~g} \mathrm{~L}^{-1}$ tryptone dissolved in deionized water). Each data point in (a), (b), (c) is the 546 average of triplicate batches with the error bars representing the maximum and minimum. 

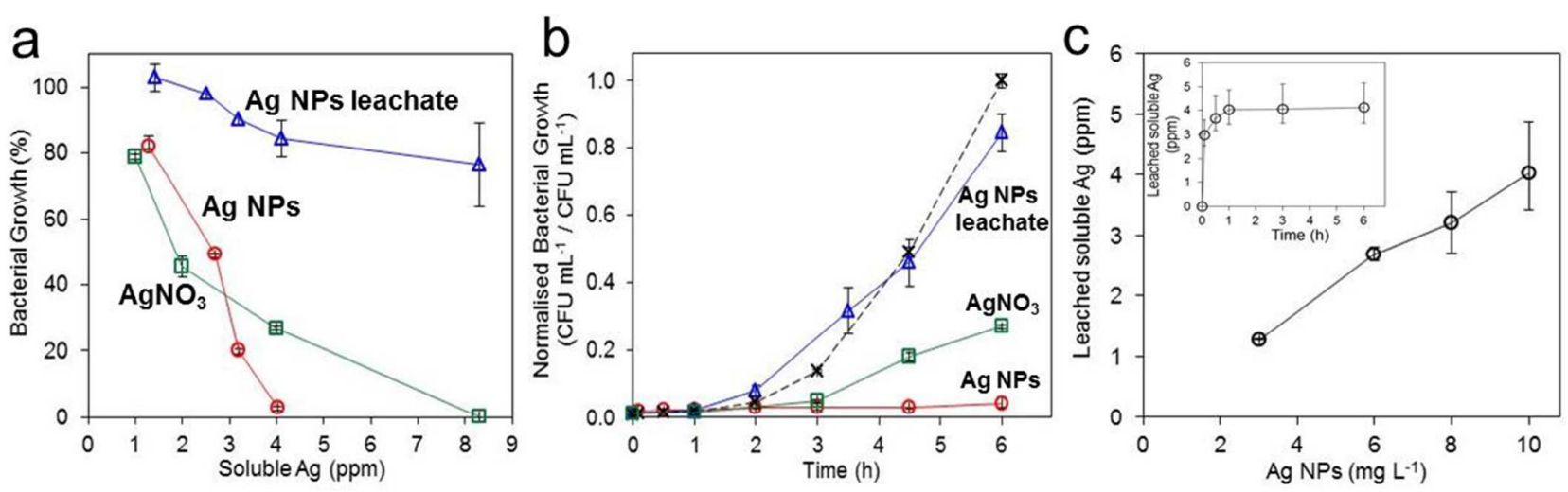

\section{Figure 1}



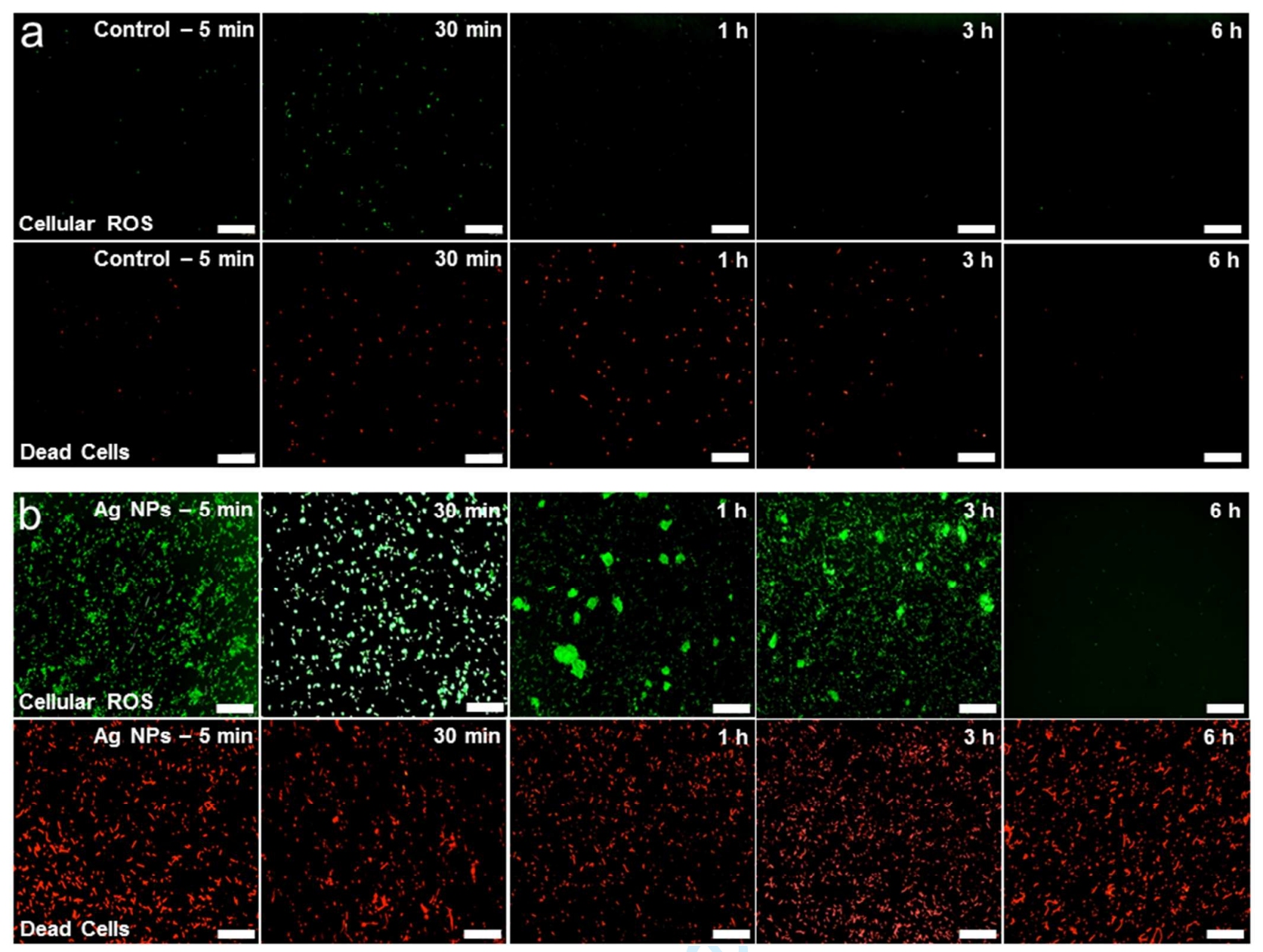

Figure 2 


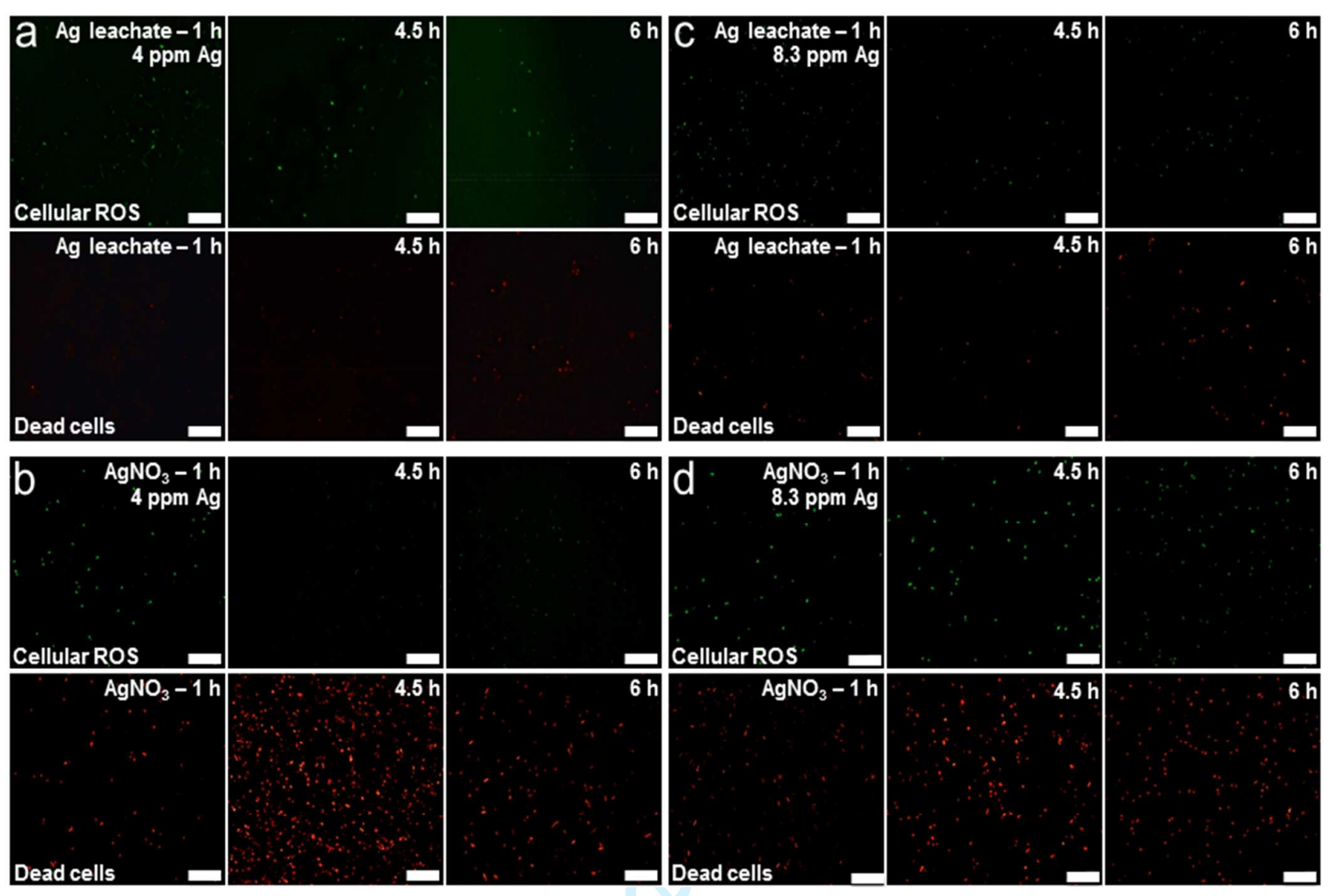

Figure 3 


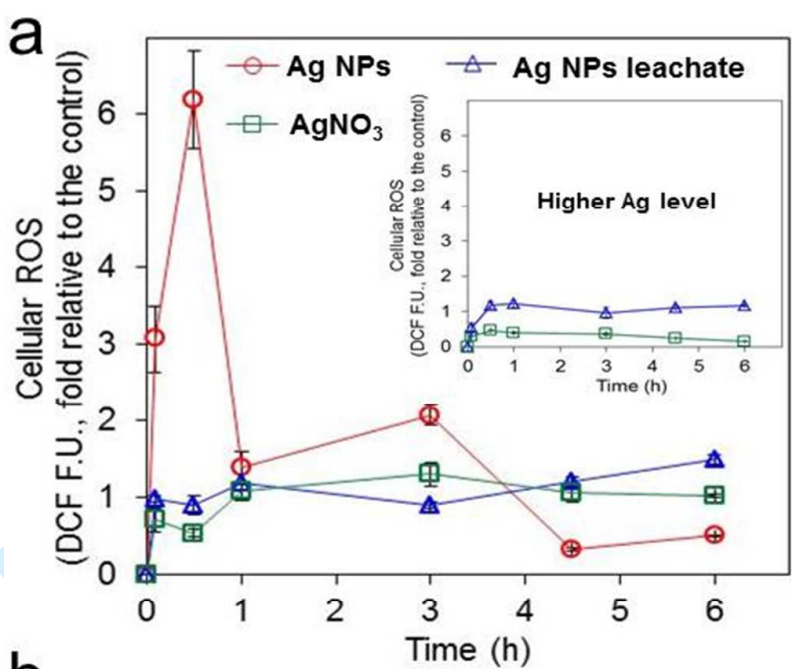

b
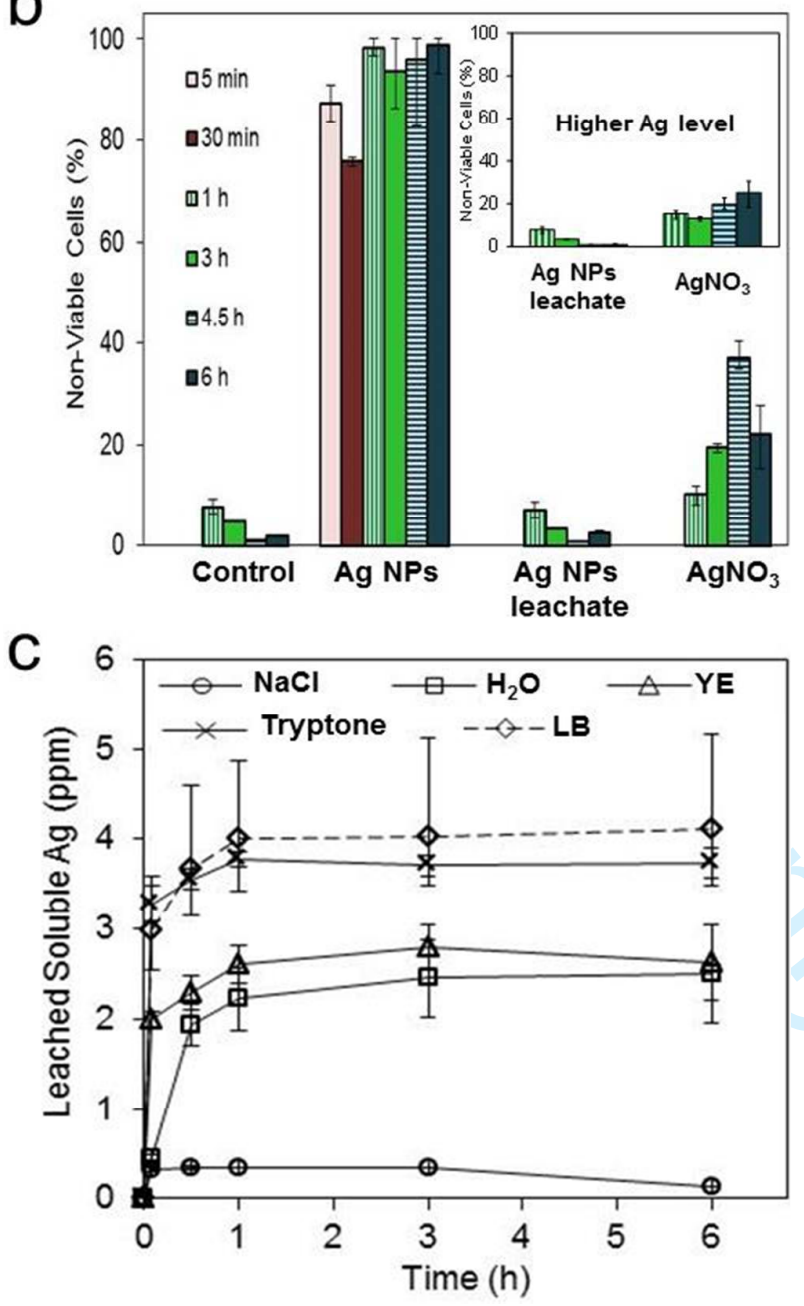

\section{Figure 4}




\title{
Nanosilver and the Microbiological Activity of the Particulate Solids versus the Leached Soluble Silver
}

\author{
Merisa B. Faiz ${ }^{1}$, Rose Amal ${ }^{1}$, Christopher P. Marquis ${ }^{2}$, Elizabeth J. Harry ${ }^{3}$, \\ Georgios A. Sotiriou ${ }^{4}$, Scott A. Rice ${ }^{5}$, Cindy Gunawan ${ }^{1,3^{*}}$
}

Supplementary Data 


\section{Quantification of the soluble and solid Ag fractions}

ICP-MS analysis was performed to determine the concentration of the leached soluble Ag and the undissolved Ag particulate residue of the Ag NPs-culture medium systems (no cells).

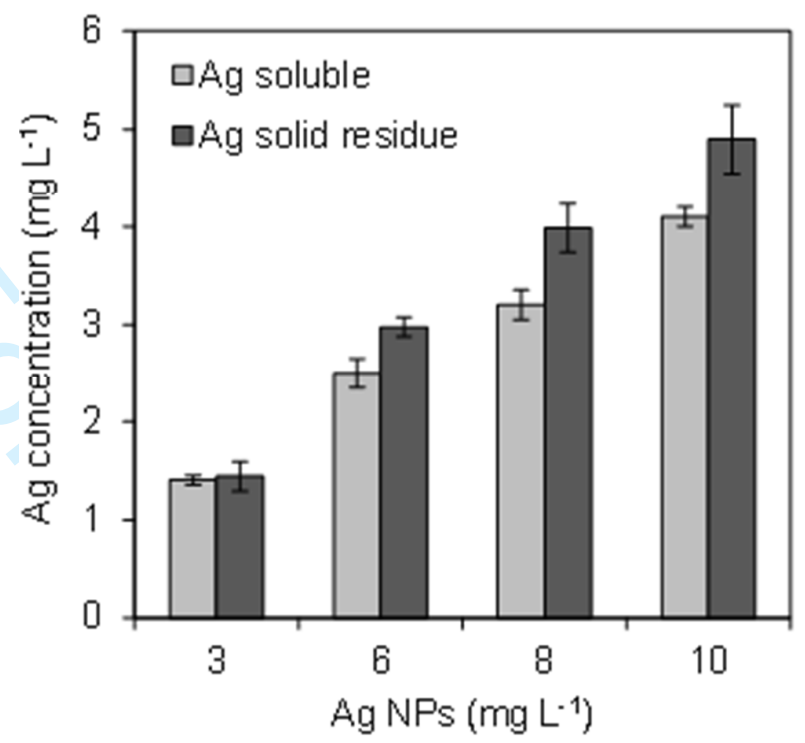

Figure S1. Concentration of the soluble and solid Ag fractions of the Ag NPs-culture medium systems (no bacteria), samples were taken at $6 \mathrm{~h}$ following NPs addition. 


\section{First order kinetic prediction of growth upon exposure to Ag leachate from NPs and}

\section{$\mathrm{AgNO}_{3}$}

The presence of non- or slowly proliferating viable cells as a result of exposure of B. subtilis to 4 and $8.3 \mathrm{ppm} \mathrm{Ag} \mathrm{leachate} \mathrm{as} \mathrm{well} \mathrm{as} \mathrm{to} \mathrm{the} \mathrm{equivalent} 4$ and $8.3 \mathrm{ppm}$ soluble $\mathrm{Ag}$ from $\mathrm{AgNO}_{3}$ salt is validated by overestimation of the predicted biomass growth based on first order kinetic, i.e. $\left[A_{n}\right] /\left[A_{n-1}\right]=e^{k t}$, where $\left[A_{n-1}\right]$ is the concentration of PI-negative (viable) cells at previous time interval. The rate coefficient $(\mathrm{k})$ is estimated from bacteria-only control growth.
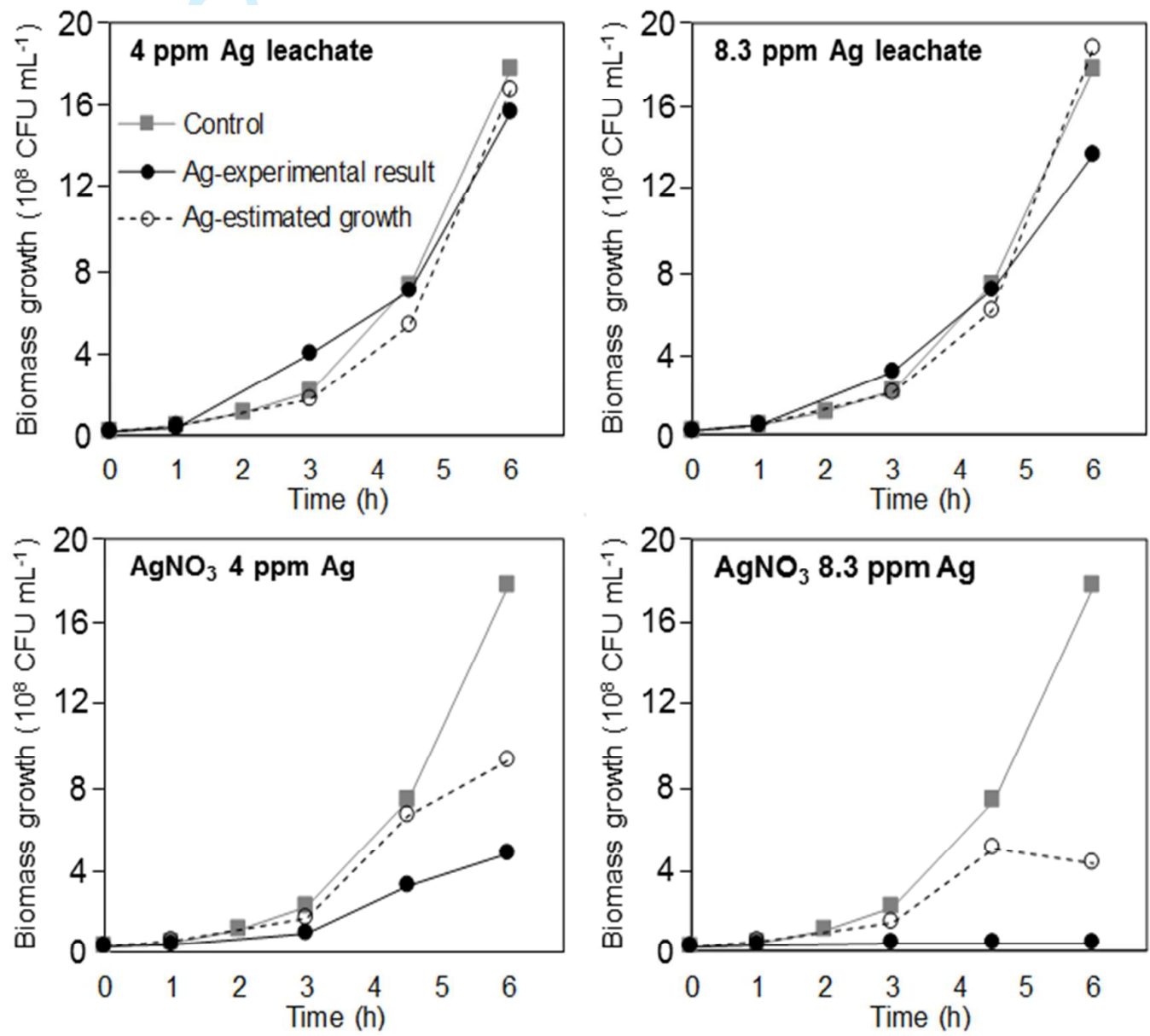

Figure S2. First order kinetic growth prediction of $B$. subtilis upon exposure to $4 \& 8.3 \mathrm{ppm} \mathrm{Ag}$ NPs leachate and to $4 \& 8.3 \mathrm{ppm} \mathrm{Ag}$ from $\mathrm{AgNO}_{3}$ as compared to the actual growth. 


\section{Statistical analysis of silver-induced cellular reactive oxygen species generation and cell}

\section{death detection}

The statistical significance of cytotoxicity of $\mathrm{Ag}$ NPs, $\mathrm{Ag}$ NPs leachate and $\mathrm{AgNO}_{3}$ relative to the bacteria-only control was analyzed by using a one-way ANOVA followed by Dunnett's posthoc analysis in Prism (GraphPad).
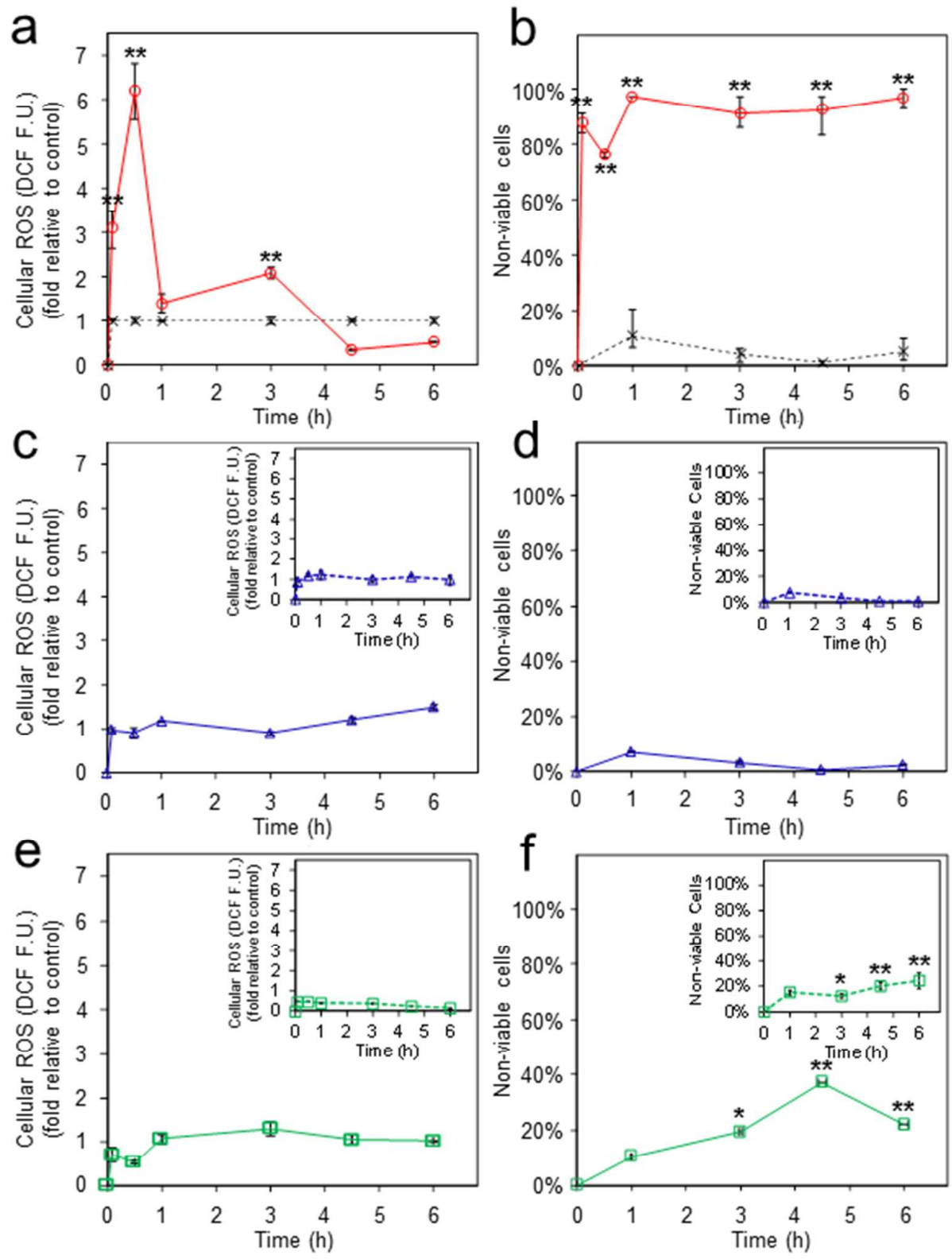

Figure S3. Statistical analysis of dynamic cellular ROS and cell death detection over the course of B. subtilis growth upon exposure to (a, b) $10 \mathrm{mg} \mathrm{Ag} \mathrm{L}^{-1} \mathrm{NPs}$ (4 ppm Ag leached into medium 
at equilibrium) (c, d) 4 ppm Ag leachate from NPs (inset is $8.3 \mathrm{ppm} \mathrm{Ag} \mathrm{leachate} \mathrm{from} \mathrm{NPs)} \mathrm{(e,} \mathrm{f)}$ 4 ppm $\mathrm{Ag}$ from $\mathrm{AgNO}_{3}$ (inset is $8.3 \mathrm{ppm} \mathrm{Ag}$ from $\mathrm{AgNO}_{3}$ ). The asterisks (*,**) correspond to $\mathrm{p}$ values of $\leq 0.01,0.001$ respectively, and indicate statistical significance relative to the bacteriaonly control (dashed lines). 

the Leached Soluble Silver

\section{Nanosilver and the Microbiological Activity of the Particulate Solids versus}

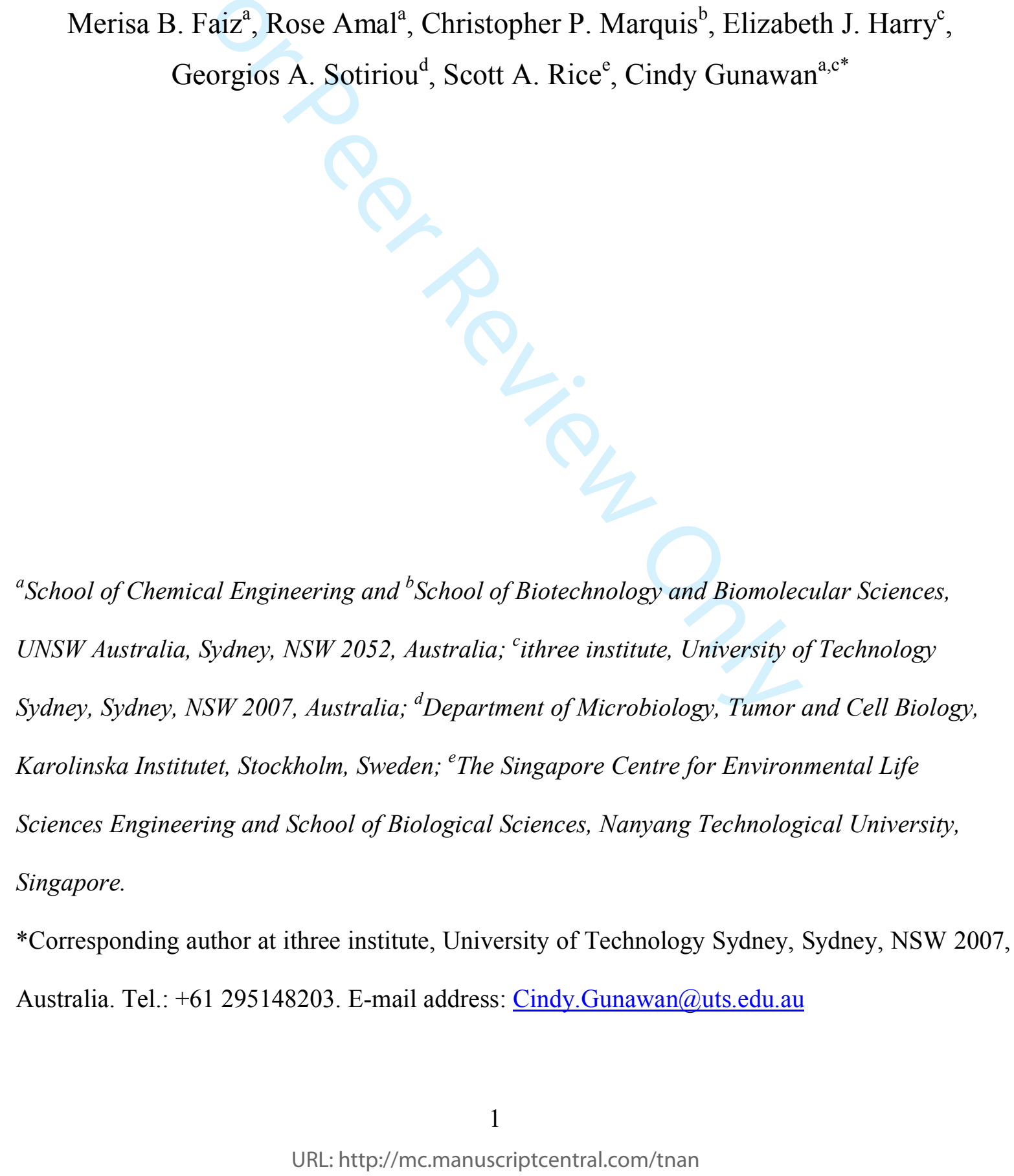




\section{Nanosilver and the Microbiological Activity of the Particulate Solids versus}

\section{the Leached Soluble Silver}

34

\section{Abstract}

Nanosilver (Ag NPs) is currently one of the most commercialized antimicrobial nanoparticles with as yet,

37 still unresolved cytotoxicity origins. To date, research efforts have mostly described the antimicrobial

38 contribution from the leaching of soluble silver, while the undissolved solid Ag particulates are often

39 considered as being microbiologically inert, serving only as source of the cytotoxic Ag ions. Here, we

40 show the rapid stimulation of lethal cellular oxidative stress in bacteria by the presence of the undissolved

$41 \mathrm{Ag}$ particulates. The cytotoxicity characteristics are distinct from those arising from the leached soluble

$42 \mathrm{Ag}$, the latter being locked in organic complexes. The work also highlights the unique oxidative stress-

43 independent bacterial toxicity of silver salt. Taken together, the findings advocate that future enquiries on

44 the antimicrobial potency and also importantly, the environmental and clinical impact of Ag NPs use,

45 should pay attention to the potential bacterial toxicological responses to the undissolved Ag particulates,

46 rather than just to the leaching of soluble silver. The findings also put into question the common use of

47 silver salt as model material for evaluating bacterial toxicity of Ag NPs.

48

49

50

51 Word count: 6472

52

53

54

55

56

57
Keywords: silver nanoparticles; Ag solids; silver leaching; toxicity; reactive oxygen species 


\section{Introduction}

The rapid development in nanotechnology has seen inorganic nanomaterials such as nanosilver, copper oxide and zinc oxide, subjected to advanced physicochemical manipulation to exhibit powerful antimicrobial activity (Gunawan et al. 2009, 2011, 2013a, Hajipour et al. 2012). Among these materials, nanosilver (silver nanoparticles, Ag NPs) is currently one of the most commercialized due to its potent and broad-spectrum antimicrobial characteristics (Consumer Products Inventory - Project on Emerging Nanotechnologies). Along with applications as core or co-antimicrobial ingredients in wound dressings and internal catheters (Ge et al. 2014), Ag NPs have also been incorporated in an increasing array of consumer products (Deardorff 2014), ranging from personal care products, textiles and household appliances to food and beverages and even children's products (Benn et al. 2010, Quadros et al. 2013). The widespread use is despite the ill-defined antimicrobial mechanisms of Ag NPs, in particular the lack of knowledge regarding the origins of cytotoxicity. The controversy has been at least one of the underlying reasons for regulatory bodies to still classify and regulate Ag NPs as regular bulk silver. Therefore, the nanoparticles are subjected to the same reporting requirements, threshold levels and toxicity tests as bulk silver, despite the mounting evidence indicating differences in their antimicrobial potency and properties (Faunce and Watal 2010). The antimicrobial activity of Ag NPs is influenced by the particles' physicochemical characteristics (e.g. size, shape, surface functional groups) as well as interactions with the particles' environment. In real-world settings of Ag NPs antimicrobial applications, the almost inevitable contact of the nanoparticles with aqueous environments, including those in the environment and in the human body, will lead to leaching of soluble silver species through oxidative dissolution of the silver metal (Trop et al. 2006, Benn and Westerhoff 2008, Liu et al. 2012, Sotiriou et al. 2012). Considerable research efforts have described the cytotoxic activity of the leached soluble silver on bacteria, even in their various forms, such as the soluble $\mathrm{Ag}(\mathrm{I})$-chloride anionic complexes (Levard et al. 2013) and organo complexes (Gunawan et al. 2009), as a result of potential interactions of the released 
84 silver with the ubiquitous presence of halides $\left(\mathrm{Cl}^{-}, \mathrm{Br}^{-}, \mathrm{I}^{-}\right)$and biomolecules in the environment 85 and in body fluids (Silver 2003, Liu et al. 2012, Eckhardt et al. 2013). Uncertainty however, still 86 lingers as to the bacterial toxicological responses to the undissolved Ag residue (Gunawan et al. 2009, Sotiriou and Pratsinis 2010, Xiu et al. 2012), that remains after leaching of silver. The bacteria (Sondi and Salopek-Sondi 2004, Mirzajani et al. 2011), but otherwise are often regarded

91 ions. This view is inclusive of the hypothesized Trojan-horse type of Ag NPs cytotoxicity,

92 whereby leaching occurs intracellularly following uptake of particles, or, the suggested cell-

93 particle contact to cause additional leaching at the cell-particle interface and in turn, increasing

94 the uptake of Ag ions by bacteria (Lemire et al. 2013, Bondarenko et al. 2013). The elucidation

95 of the source of Ag NPs cytotoxicity will not only clarify the nanoparticles' 'true' antimicrobial

96 potency in real-world applications, but will also contribute to more accurate assessments of their

97 long-term impact on the environment and human health.

Here, we investigated the origins of Ag NPs cytotoxicity through detailed investigations of bacterial toxicological responses to the 'overall' presence of nanosilver (i.e. both leached soluble $\mathrm{Ag}$ and $\mathrm{Ag}$ particulate residue are present in the systems), as compared to those of the

forms of nano-sized $\mathrm{Ag}(\mathrm{I})$ or metallic $\mathrm{Ag}^{0}$ coated on or impregnated in support materials (Gunawan et al. 2017). As model material, the current work used nanosilver in the form of nanosized $\mathrm{Ag}_{2} \mathrm{O}$ deposits $\left(\mathrm{d}_{T E M}=2 \mathrm{~nm}(\right.$ Gunawan et al. 2009)) homogenously dispersed on the surface of inert $\mathrm{TiO}_{2}$ support $\left(\mathrm{d}_{T E M}=30 \mathrm{~nm}(\right.$ Gunawan et al. 2009)). It is noteworthy to point out that studies have observed discrepancies on the leaching behaviour as well as capability of cellular oxidative stress stimulation of $\mathrm{Ag}(\mathrm{I})$ versus $\mathrm{Ag}^{0}$ nanoparticles (Gunawan et al. 2009, Gunawan et al. 2013b). Nonetheless, the generated knowledge of cellular responses to the two 
110 fundamental forms of nanosilver-derived microbiologically active components, that is, the

111 leached soluble silver and the solid Ag particulates in the present study, is relevant to the

112 countless nanosilver design with variation in the particle's properties (e.g. size, shape and

113 oxidation states). This facile approach enables unambiguous elucidation of the source of

114 nanoparticulate cytotoxicity without the need to employ simulation materials, such as soluble Ag

115 salt (Gunawan et al. 2009, Sotiriou and Pratsinis 2010, Gunawan et al. 2011, Bondarenko et al.

116 2013, Ivask et al. 2014), which, as also shown in the current work, exhibits different cytotoxicity

117 characteristics. We report cytotoxic activity of the solid Ag particulates on bacteria, distinct from 118 the leached soluble silver.

\section{Methods}

\section{Synthesis of Ag NPs and Preparation of Ag leachate from NPs}

$122 \mathrm{The} 5 \mathrm{at} \% \mathrm{Ag} / \mathrm{TiO}_{2}$ nanoparticles as finely dispersed $\mathrm{Ag}_{2} \mathrm{O}$ on inert $\mathrm{TiO}_{2}$ support were synthesized using the flame spray pyrolysis (FSP) technique as earlier described (Gunawan et al. $2013 \mathrm{~b}$, note that at $\%$ refers to the percentage of $\mathrm{Ag}$ atom relative to the total number of atoms in

125 the particle). TEM images of the particles and XPS spectra that confirm the presence of silver (I)

126 oxide are available (Gunawan et al. 2009). The Ag-leachate was prepared by aseptically pre-

127 dissolving known amounts of $\operatorname{Ag}$ NPs $\left(3,6,8,10 \mathrm{mg} \mathrm{Ag} \mathrm{L}^{-1}\right)$ in sterile Luria Bertani (LB) broth $128\left(5 \mathrm{~g} \mathrm{~L}^{-1}\right.$ yeast extract, $10 \mathrm{~g} \mathrm{~L}^{-1}$ tryptone, $5 \mathrm{~g} \mathrm{~L}^{-1} \mathrm{NaCl}$ in deionized water) at $37^{\circ} \mathrm{C}, 280 \mathrm{rpm}$ under

129 dark conditions for $6 \mathrm{~h}$, unsonicated. The undissolved particulates (mean aggregate size $=1.09 \pm$ $130 \quad 0.03 \mu \mathrm{m}$ by dynamic light scattering (Gunawan et al. 2009)) were removed by centrifugation

$131(5,000 \mathrm{rpm})$ followed by filtration of the leachate with $0.22 \mu \mathrm{m}$ polyethersulfone membrane

132 (Millipore Express). Comparable light scattering intensity of the filtered Ag leachate to that of 133 the filtered LB medium confirmed the removal of the solid Ag residue (data not shown). The 134 concentration of soluble silver in the filtered Ag leachate was determined by inductively coupled 
135 plasma mass spectrometry (ICP-MS) (Nexion 300D, PerkinElmer). ICP-MS analysis was also

136 performed on the undissolved $\mathrm{Ag}$ residue (3-4 h digestion with $70 \%(\mathrm{v} / \mathrm{v}) \mathrm{HNO}_{3}$ to dissolve the

137 Ag solid). This Ag solid concentration (no cells) reflected, at least in approximation, the

138 presence of the undissolved Ag fraction in the nanoparticle-bacteria exposure systems (note the

139 comparable leaching of Ag NPs in the presence and absence of bacteria, Figure 1 and S1,

140 Supplementary Data). The ICP-MS analysis of the (digested) solid Ag residue and the

141 corresponding Ag leachate fractions (undigested) found that their concentrations added up

142 (within 10-15\%) to the nominal total Ag concentrations of the nanoparticles (Figure S1). Finally,

143 the ICP-MS analysis of digested leachate samples found comparable Ag concentrations before

144 and after digestion, which further validated the removal of the solid Ag residue. Suspended

$145 \mathrm{Ag} / \mathrm{TiO}_{2}$ particulates in the growth medium is expressed as $\mathrm{mg} \mathrm{L}^{-1}$ to reflect their heterogeneous

146 presence, while the homogeneous nature of soluble Ag is referred to in ppm.

148 Bacterial Growth Studies with $\mathrm{Ag} \mathrm{NPs}$, Ag leachate and $\mathrm{AgNO}_{3}$ salt

149 The growth experiments on Bacillus subtilis strain UNSW 448700 were carried out in triplicate 150 in $\mathrm{LB}$ culture medium at $37^{\circ} \mathrm{C}, 280 \mathrm{rpm}$ under dark conditions for $6 \mathrm{~h}$. To prepare the bacterial

151 inoculum, a single agar plate colony was cultured overnight at $30^{\circ} \mathrm{C}, 220 \mathrm{rpm}$ in $\mathrm{LB}$ broth. A

152 measured volume of $1-2 \mathrm{~mL}$ of the overnight culture (typical $\mathrm{OD}_{600}$ of 6-8) was transferred into

$15350 \mathrm{~mL}$ fresh LB broth for a further $0.5-1 \mathrm{~h}$ conditioning at $37^{\circ} \mathrm{C}, 280 \mathrm{rpm}$. For the $\mathrm{Ag} \mathrm{NPs}$ and

$154 \mathrm{AgNO}_{3}$ exposure, pre-weighed Ag NPs (1.1x of the intended dosage) and $0.5 \mathrm{~mL}(110 \mathrm{x}$

155 concentrated of the intended dosage) solution of $\mathrm{AgNO}_{3}$ were aseptically added into $50 \mathrm{~mL}$ and

$15649.5 \mathrm{~mL}$ LB respectively. The experiments were initiated by the addition of $5 \mathrm{~mL}$ bacterial

157 inoculum into the $50 \mathrm{~mL}$ broth containing suspended Ag NPs or dissolved silver salt $\left(\mathrm{OD}_{600}\right.$

158 bacteria initial $=0.04$, corresponding to $\sim 2 \times 10^{7} \mathrm{cfu} \mathrm{mL}^{-1}$ ). For the Ag leachate exposure, $5 \mathrm{~mL}$

159 of the bacterial inoculum was added into $50 \mathrm{~mL}$ LB containing 1.1x concentrated pre-leached $\mathrm{Ag}$ 
160 NPs (particle-free). The growth profiles were determined by $\mathrm{OD}_{600}$ measurement of the biomass

161 (UV/Vis spectrophotometer, Hitachi U-1100) and the growth inhibiting effects were assessed

162 relative to controls with no added silver. A cell-free silver control (particulates or soluble silver)

163 was employed as a reference to obtain the $\mathrm{OD}_{600}$ corresponding to the bacteria. The

164 corresponding leaching profile of Ag NPs during the bacterial exposure was measured by ICP-

165 MS (Nexion 300D, PerkinElmer). For this purpose, a measured volume was sampled from the

166 NPs-exposed culture, centrifuged $(5,000 \mathrm{rpm})$ then filtered with the $0.22 \mu \mathrm{m}$ membrane to

167 remove the bacteria and Ag solid. The resulting solution was $100 \mathrm{x}$ diluted in deionized water and

168 subjected to the ICP-MS analysis.

169

\section{Detection of Intracellular ROS and Cell Viability}

171 The measurement of cellular ROS generation was performed using the cell permeable oxidative

172 reporter dye $\mathrm{H}_{2}$ DCFDA (2',7'-dichlorodihydrofluorescein diacetate, Sigma-Aldrich). Following

173 its uptake, cellular esterases cleave the diacetate moieties of $\mathrm{H}_{2}$ DCFDA to form $\mathrm{H}_{2} \mathrm{DCF}$, which

174 readily transforms to the fluorescent DCF when reacts with ROS. The cell viability assay was

175 based on the fluorescent nucleic acid dye propidium iodide (Sigma-Aldrich) staining. PI enters

176 cells with damaged cytoplasmic membrane, while being excluded by healthy cells. Following

177 removal of the culture medium by centrifugation, samples from the Ag NPs, Ag leachate and

$178 \mathrm{AgNO}_{3}$ exposure systems (and the silver-free controls) were washed and re-suspended in sterile

179 saline $\left(8 \mathrm{~g} \mathrm{~L}^{-1} \mathrm{NaCl}, 0.2 \mathrm{~g} \mathrm{~L}^{-1} \mathrm{KCl}\right)$ at $2.5 \times 10^{8} \mathrm{CFU} \mathrm{mL} \mathrm{m}^{-1}$. Independent cellular ROS and cell

180 viability assays were carried out with $10 \mu \mathrm{M} \mathrm{H} \mathrm{H}_{2}$ DCFDA and $30 \mu \mathrm{M}$ PI for $1 \mathrm{~h}$ and 15 min

181 respectively, at room temperature under dark conditions. The stained cells were washed with

182 saline and analysed by flow cytometry (FACSCanto ${ }^{\mathrm{TM}}$ II, BD Bioscience) at $488 \mathrm{~nm}$ excitation

183 with $530 \mathrm{~nm}$ and $670 \mathrm{~nm}$ emission filter settings for the detection of DCF and PI fluorescence

184 respectively. DCF fluorescence was also measured using a microplate reader $\left(\right.$ Ensight $^{\mathrm{TM}}$

185 Multimode, Perkin Elmer) at $492 \mathrm{~nm}$ and $520 \mathrm{~nm}$ excitation and emission filter settings 
186 respectively. The stained cells were also visualized with a BX51WI fluorescence microscope

187 (Olympus) with 460-490 nm excitation filter settings.

188

189

\section{Results and discussion}

190

Bacterial growth inhibition: Activity of the solid Ag particulates, the leached soluble Ag and

\section{1 silver salt}

192 To distinguish the cytotoxicity or antimicrobial contribution of the leached soluble Ag and the

193 undissolved Ag particulates, we exposed a model bacteria B. subtilis UNSW 448700 to 0 - 10

$194 \mathrm{mg} \mathrm{Ag} \mathrm{L}{ }^{-1} \mathrm{NPs}\left(\mathrm{Ag} / \mathrm{TiO}_{2}\right)$ and compared the bacterial growth to that of the corresponding

195 leachate-only systems, as a function of soluble silver detected in the exposure systems. The

196 leachate samples were prepared by aseptically pre-dissolving Ag NPs in culture medium

197 followed by removal of the solid Ag residue. Firstly, as shown in Figure 1a, the dose-response

198 growth inhibiting effects of the Ag NPs correlates with the increasing concentration of soluble

199 silver that leached from the NPs. The extent of growth of B. subtilis was reduced to $\sim 80 \%$ upon

200 exposure to $3 \mathrm{mg} \mathrm{Ag} \mathrm{L}{ }^{-1} \mathrm{NPs}$ (1.3 ppm silver leached into the culture medium at equilibrium)

201 relative to silver-free control cultures after $6 \mathrm{~h}$. The control cultures were characterized by a

202 relatively short lag phase of $1 \mathrm{~h}$, followed by 3 to $4 \mathrm{~h}$ active exponential growth phase before

203 entering the stationary phase at $6 \mathrm{~h}$ (Figure $1 \mathrm{~b})$. Increasing the NPs dosage to $6 \mathrm{mg} \mathrm{Ag} \mathrm{L}^{-1}(2.7$

204 ppm leached Ag) saw 50\% bacterial growth, while almost complete growth suppression was

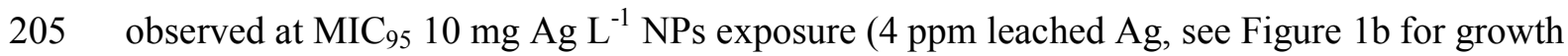

206 profile, $\mathrm{MIC}_{95}$ is minimum inhibitory concentration that cause $5 \%$ growth relative to the control).

207 At all of the tested Ag NPs loading, leaching of Ag from NPs was rapid, with detection of $\sim 70 \%$

208 soluble $\mathrm{Ag}$ (relative to the leached $\mathrm{Ag}$ concentration detected at equilibrium) within 5 min of the

$209 \mathrm{Ag}$ NPs-bacterial exposure (see Figure 1c inset for leaching profile of $10 \mathrm{mg} \mathrm{Ag} \mathrm{L}^{-1} \mathrm{NPs}$ ).

210 Equilibrium was reached in $1 \mathrm{~h}$ with the soluble Ag concentration remained constant afterwards,

211 indicating absence of the Ostwald ripening phenomenon that refers to re-deposition of the 
212 leached Ag on larger particulates (Sotiriou et al. 2012). Increasing the Ag NPs loading saw

213 detection of elevated soluble Ag concentration at equilibrium, with the extent of leaching

214 essentially comparable at $38-40 \%$ relative to the total added Ag (Figure 1c). This is consistent

215 to earlier studies under comparable conditions (Gunawan et al. 2009, Sotiriou and Pratsinis

216 2010) with the relatively high degree of leaching was due to, at least in part, the presence of

217 organics in the culture medium as shown later in this study. Note that at all of the tested Ag NPs

218 loadings, similar extent of leaching were observed in the absence of bacteria, therefore excluding

219 the possibility of microbial-induced leaching of Ag (Figure S1).

220

221

222

223

224

225

226

227

228

229

230

231

232

233

234

235

236

Despite the correlation between Ag NPs growth inhibiting effects and Ag leaching, a comparison with bacterial growth in the corresponding leachate-only systems yields an interesting observation. Exposure of B. subtilis to the pre-leached soluble Ag in fact resulted in much less growth inhibition when compared to those of the corresponding Ag NPs samples (Figure 1a). The presence of $\sim 1.3 \mathrm{ppm} \mathrm{Ag} \mathrm{leachate} \mathrm{for} \mathrm{example,} \mathrm{was} \mathrm{benign} \mathrm{to} \mathrm{the} \mathrm{cultures} \mathrm{as}$ they grew to a similar extent as the silver-free control cultures after $6 \mathrm{~h}$. This was in contrast to the $\sim 20 \%$ growth reduction of the bacteria when exposed to the corresponding $3 \mathrm{mg} \mathrm{Ag} \mathrm{L}^{-1} \mathrm{NPs}$ with comparable leached soluble Ag content. At higher exposure, the bacterial growth in 4 ppm Ag leachate system was $\sim 85 \%$ relative to the control cultures (refer to Figure $1 \mathrm{~b}$ for growth profile), in contrast to the near complete growth suppression observed in the corresponding 10 mg Ag L ${ }^{-1}$ NPs system. Even doubling the concentration of Ag leachate to $8.3 \mathrm{ppm}$ only slightly reduced the bacterial growth to $\sim 75 \%$. The findings suggest predominant cytotoxicity contribution from the undissolved Ag particulates, rather than that arising from the leached soluble Ag. Further antimicrobial simulation with an equivalent concentration of soluble Ag from $\mathrm{AgNO}_{3}$ salt as shown in Figure 1a, saw more severe growth inhibiting activity of the salt. In the presence of $4 \mathrm{ppm}$ soluble $\mathrm{Ag}$ from $\mathrm{AgNO}_{3}$ for example, $\sim 25 \%$ B. subtilis growth was 
237 observed relative to the control cultures after $6 \mathrm{~h}$ (growth profile is shown in Figure 1b), in

238 contrast to the $\sim 85 \%$ growth in the leachate system with comparable Ag concentration. Such

239 differences in cytotoxicity may arise from unique cellular physiological responses to the

240 different silver species; the leached soluble Ag and the undissolved Ag particulates from Ag

241 NPs, and the soluble silver from silver salt, as investigated in the following.

242

243 Dynamic stimulation of cellular oxidative stress and cell death

244 We carried out dynamic tracking of intracellular reactive oxygen species (ROS) generation

245 (measured by $\mathrm{H}_{2}$ DCFDA assay) and cell viability (measured by propidium iodide assay,

246 whereby PI enters cells with damaged cytoplasmic membrane, which is indicative of cell death)

247 over the $6 \mathrm{~h}$ growth course of $B$. subtilis in the presence of the various forms of silver; the Ag

248 NPs ( $\mathrm{MIC}_{95} 10 \mathrm{mg} \mathrm{Ag} \mathrm{L}^{-1}$ as reference point, contained 4 ppm leached $\mathrm{Ag}$ ), its corresponding

249 Ag leachate system (4 ppm Ag) and the equivalent $\mathrm{AgNO}_{3}$ system (4 ppm Ag).

250

251 The solid Ag particulates and the leached soluble Ag

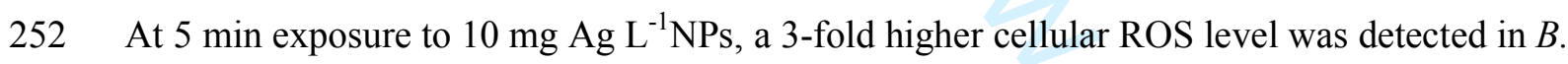

253 subtilis relative to the basal ROS levels of the silver-free control cultures, which are by-products

254 of aerobic metabolism in bacteria (Choi and Hu 2008, Gunawan et al. 2011, Eckhardt et al.

255 2013) (Figure 2a, 2b, 4a). Within 30 min of Ag NPs exposure, the cellular ROS level doubled to

$256 \sim 6$-fold of the control. A secondary oxidative stress response, the cellular ROS stimulation has

257 been increasingly realized as one of the major cellular toxicological responses to Ag NPs in

258 bacteria (Choi and Hu 2008, Hwang et al. 2008, Lemire et al. 2013, Gunawan et al. 2013b). The

259 ROS generation is thought to result from destruction of the iron-sulfur [4Fe-4S] clusters of

260 proteins by Ag metal (Xu and Imlay 2012, Lemire et al. 2013) and in turn, releasing the Fenton-

261 active free $\mathrm{Fe}$ into the cytoplasm for subsequent reaction with cellular $\mathrm{H}_{2} \mathrm{O}_{2}$ to produce hydroxyl 
262 radicals $\left(\mathrm{OH}^{*}\right)$ (Imlay et al. 1988). Alternatively, indirect destruction of the iron-sulfur clusters

263 could result from inhibition of respiratory enzymes by Ag NPs in bacteria (Li et al. 2010, 2011).

264 The resulting premature leakage of electrons to oxygen will generate superoxide radicals $\left(\mathrm{O}_{2}{ }^{\circ}\right)$

265 (Imlay 2003) that in turn again, induces the release of free Fe from iron-sulfur clusters in

266 proteins (Kohanski et al. 2007). Indeed, there have been reports on the cytoplasmic presence of

267 the solid Ag particulates upon bacterial exposure to Ag NPs, as well as the presence of the solids

268 within the bacterial membrane layers (Morones et al. 2005, Grigor'eva et al. 2013, Pal et al.

269 2007). Here, $75-90 \%$ PI-positive non-viable bacteria had been detected within 5 to $30 \mathrm{~min}$

270 exposure to Ag NPs, then close to $100 \%$ bactericidal or cell death toxicity at as early as $1 \mathrm{~h}$

271 exposure (Figure 2a, 2b, 4b), which indicates cytoplasmic membrane as one of the target

272 destruction sites of the Ag NPs-stimulated cellular ROS (1-8\% non-viable cells were detected in

273 the control cultures over the $6 \mathrm{~h}$ growth course) (D'Autreaux et al. 2007, Lemire et al. 2013). As

274 expected, the levels of cellular ROS drastically dropped following the rapid high level

275 stimulation, with the majority if not all of the bacterial population were already killed (Sintubin

276 et al. 2011, Gunawan et al. 2013b). Up to this stage, the data suggest that the generation of high

277 levels of cellular ROS and associated bacteria killing was likely to be responsible for the near

278 complete suppression of $B$. subtilis growth (Figure 1a, 1b).

279

280

281

282

283

284

Interestingly, such cellular ROS stimulation was absent in the bacteria when studied in the corresponding 4 ppm Ag leachate system. Over the 6 h growth course, only basal ROS levels, comparable to those of the silver-free control cultures were detected (Figure 2a, 3a, 4a) and not surprisingly, the little to no changes in the fraction of non-viable cells relative to the control (Figure 2a, 3a, 4b). The stimulation of lethal levels of cellular oxidative stress by the presence of solid Ag particulates therefore suggests their substantial contribution to the cytotoxicity effects observed in the growth studies. Recalling the observed $~ 15 \%$ growth inhibition of the bacteria in 
287 the presence of $4 \mathrm{ppm} \mathrm{Ag} \mathrm{leachate} \mathrm{(Figure} \mathrm{1a,} \mathrm{1b),} \mathrm{it} \mathrm{would} \mathrm{be} \mathrm{reasonable} \mathrm{to} \mathrm{deduce} \mathrm{that} \mathrm{the}$

288 exposure only resulted in sub-lethal cytotoxicity, causing a minor fraction of the viable cells

289 uncultivable or slowly proliferating, as further indicated by our growth prediction based on the

290 fraction of viable cells (Figure S2). Indeed, doubling the Ag leachate concentration to $8.3 \mathrm{ppm}$

291 still saw typical cellular ROS (Figure 3c, 4a inset) and dead cells (Figure 3c, 4b inset) detection

292 as those of the control cultures, despite the slightly higher growth suppression, at $25 \%$ (Figure

293 1a).

294

295 The leached soluble Ag and silver salt

296 The minimal cellular ROS stimulation was also seen upon exposure of $B$. subtilis to the

297 equivalent 4 ppm soluble $\mathrm{Ag}$ from $\mathrm{AgNO}_{3}$. Similar to the $4 \mathrm{ppm}$ Ag leachate system, no elevated

298 level of cellular ROS was observed over the $6 \mathrm{~h}$ growth course relative to the control cultures

299 (Figure 2a, 3b, 4a). Unlike the leachate samples however, up to $40 \%$ non-viable cells were

300 detected in the salt system (Figure $3 b, 4 b$ ), indicating attacks on cytoplasmic membrane

301 (Eckhardt et al. 2013). Considering the comparable Ag content, such discrepancies in

302 cytotoxicity are most likely to result from differences in the chemical speciation of the soluble

303 silver, as herein described. Our Ag NPs leaching study (at the MIC $9510 \mathrm{mg} \mathrm{Ag} \mathrm{L}^{-1} \mathrm{NPs}$ ) in the

304 individual culture medium components revealed a characteristic trend of complexation-assisted

305 dissolution of nanoparticles (Gunawan et al. 2011), with higher extent of Ag leaching in the

306 peptide-rich components, in particular tryptone (90\% leaching relative to the total added Ag),

307 compared to those in the deionized water (60\% leaching) or $\mathrm{NaCl}(10 \%$ leaching) (Figure $4 \mathrm{c})$. A

308 soft Lewis acid, $\operatorname{Ag}(\mathrm{I})$ forms silver-peptide complexes upon its release from NPs (Bolea et al.

309 2014), which is most likely to result from its strong affinity to the $\mathrm{NH}_{\mathrm{x}}$ donor groups of histidine

$310\left(\mathrm{NH}^{+}\right)$, arginine $\left(-\mathrm{NH}_{2}{ }^{+}\right)$and lysine $\left(-\mathrm{NH}_{3}{ }^{+}\right)$amino acids and also to the thiol $\left(-\mathrm{S}^{-}\right)$donor groups

311 of cysteine and methionine amino acids (Eckhardt et al. 2013). Silver-peptide complexes also

312 form with $\mathrm{AgNO}_{3}$ (Bolea et al. 2014), with a fraction of silver is thought to remain as free ions in 
313 the organic-rich medium (Percival et al. 2005). Thermodynamically feasible, the co-existence of

314 free metal ions and organo metal complexes has been reported for the chemical speciation of

315 soluble copper salts, also a soft Lewis acid metal, in similar culture medium as that used here

316 (Gunawan et al. 2011) (note that the current technology for elemental analysis does not

317 differentiate free Ag ions to those locked in organo complexes (Eckhardt et al. 2013)). When

318 compared to free Ag ions, the hindered transport of the bulkier silver-peptide complexes into

319 bacteria (Solioz and Odermatt 1995) is thought to be at least in part, responsible for the

320 passivated, in this case, sub-lethal cytotoxicity of the Ag leachate. Unlike free Ag ions, research

321 indicates that soluble organo Ag complexes are not recognized by the P-type ATPase transporter

322 present in bacteria (Luoma 2008). As also observed in the current study with the $\mathrm{AgNO}_{3}$ systems,

323 exposure of bacteria to Ag ions has been reported to suppress their proliferation, which was

324 indicated to result from a ROS-independent inhibition of metabolic enzymes (dehydratases) (Xu

325 and Imlay 2012), the lack of cellular ROS stimulation also apparent in this work. Further,

326 complete suppression of $B$. subtilis growth was seen at $8.3 \mathrm{ppm} \mathrm{Ag}$ from $\mathrm{AgNO}_{3}$ (Figure 1a),

327 despite there being no change in the fraction of non-viable cells when compared to the $4 \mathrm{ppm} \mathrm{Ag}$

328 exposure (Figure 3d, 4b inset). Our growth prediction based on the fraction of viable cells

329 indicates major presence of non- or slowly proliferating viable cells with the $\mathrm{AgNO}_{3}$ exposure

330 (Figure S2). This loss in replication could also result from the known interactions of Ag ions

331 with DNA in bacteria (most likely with the phosphorus moieties) causing DNA condensation

332 (Feng et al. 2000). The seemingly higher cytotoxic effects of Ag ions as compared to the organo

333 Ag complexes are in agreement with other bacterial studies, whereby extracellular presence of

334 thiol-containing reduced gluthathione (GSH) as silver complexing agent lowered the

335 antimicrobial activity of Ag ions on the Gram-positive Staphylococcus aureus and the Gram-

336 negative Escherichia coli and Pseudomonas aeruginosa (Mulley et al. 2014). Finally, the

337 detection of only basal cellular ROS levels in the $\mathrm{AgNO}_{3}$ exposure systems, even at the double

$3388.3 \mathrm{ppm} \mathrm{Ag}$ (Figure $3 \mathrm{~d}, 4 \mathrm{a}$ inset), rules out the oxidative stress stimulation as the main 
339 mechanisms of $\mathrm{AgNO}_{3}$ cytotoxicity. Indeed, studies have found no differences in the

340 antimicrobial activity of Ag ions under aerobic and anaerobic conditions on bacteria (Sintubin et

341 al. 2011).

342

343 Conclusions

344 Here, we report multiple cytotoxicity origins of Ag NPs towards bacteria. Presence of

345 undissolved Ag particulates in a biological environment is not inert. In their presence, rapid

346 generation of lethal cellular ROS levels were detected in bacteria, while the corresponding

347 leached soluble Ag, being locked in organo complexes, only imparts sub-lethal cytotoxicity. The

348 observed differences in bacterial toxicological responses to the solid versus soluble Ag

349 corroborate earlier reports on the distinct extent of growth inhibiting activity of the Ag NPs'

350 soluble and solid components (Gunawan et al. 2009, Sotiriou and Pratsinis 2010). With regard to

351 the widespread use of Ag NPs, the resolved unique toxicological responses are expected to result

352 in better recognition of the antimicrobial potency of the nanoparticles in real-world settings and

353 importantly, the long-term impact. Research inquiries have shown elevated and persistent

354 presence of silver in wounds, bladder and even in sewage and estuaries, being associated with

355 the intended or in some cases, accidental release from nanosilver applications; the use of wound

356 dressings, pesticides and washing machines are among the examples (Chen et al. 2004, Trop et al.

357 2006, Reidy et al. 2013, Donner et al. 2015, Beddow et al. 2017). The current findings imply

358 bacterial toxicological responses to not only the leached soluble Ag, but also the Ag particulates

359 in the microbial habitats. Indeed, studies have observed disruptions in the dynamic and balance

360 of microbial communities from natural aquatic waters upon exposure to nanosilver (Das et al.

3612012 , Beddow et al. 2017), with the work also detecting presence of soluble Ag and aggregates

362 of Ag from nanosilver in these environmental samples (Beddow et al. 2017). The resolved

363 toxicological responses is key to the elucidation of the recently discovered bacterial potential for

364 adaptation to Ag NPs cytotoxicity (Das et al. 2012, Gunawan et al. 2013b). Finally, the work 
365 highlights the unsuitability of soluble silver salt as model material for Ag NPs cytotoxicity in

366 biological environments, noting a distinct ROS-independent antimicrobial characteristic of

367 soluble $\mathrm{Ag}$ when supplied as $\mathrm{AgNO}_{3}$ salt.

368

369 Acknowledgments

370 This work was produced with the financial assistance of the Australian Research Council under

371 the ARC Australian Laureate Fellowship Program and the University of Technology Sydney

372 under the Chancellor's Postdoctoral Research Fellowship Program.

373

374

375 The authors declare no conflict of interest.

\section{Declaration of interest}

377

378

379

380

381

382

383

384

385

386

387

388

389

390

391

\section{References}

Beddow J, Stolpe B, Cole PA, Lead JR, Sapp M, Lyons BP, et al. 2017. Nanosilver inhibits nitrification and reduces ammoniaoxidising bacterial but not archaeal amo $A$ gene abundance in estuarine sediments. Environ Microbiol 19: 500-510.

Benn TM, Westerhoff P. 2008. Nanoparticle silver released into water from commercially available sock fabrics. Environ Sci Technol 42: 4133-4139.

Benn T, Cavanagh B, Hristovski K, Posner JD, Westerhoff P. 2010. The release of nanosilver from consumer products used in the home. J Environ Qual 39: 1875-1882.

Bolea E, Jiménez-Lamana J, Laborda F, Abad-Álvaro I, Bladé C, Arola L, et al. 2014. Detection and characterization of silver nanoparticles and dissolved species of silver in culture medium and cells by AsFIFFF-UV-Vis-ICPMS: application to nanotoxicity tests. Analyst 139: 914-922.

Bondarenko O, Ivask A, Käkinen A, Kurvet I, Kahru A. 2013. Particle-cell contact enhances antibacterial activity of silver nanoparticles. PLoS One 8: e64060. 
392 Chen J, Han CM, Yu CH. 2004. Change in silver metabolism after the application of nanometer

393 silver on burn wound. Chin J Burns 20: 161-163.

394 Choi O, Hu Z. 2008. Size dependent and reactive oxygen species related nanosilver toxicity to $395 \quad$ nitrifying bacteria. Environ Sci Technol 42: 4583-4588.

396 Das P, Williams CJ, Fulthorpe RR, Hoque ME, Metcalfe CD, Xenopoulos MA. 2012. Changes

397 in bacterial community structure after exposure to silver nanoparticles in natural waters.

$398 \quad$ Environ Sci Technol 46: 9120-9128.

399 D'Autreaux B, Toledano MB. 2007. ROS as signalling molecules: mechanisms that generate

$400 \quad$ specificity in ROS homeostasis. Nat Rev Mol Cell Biol 8: 813-824.

401 Deardorff J, 2014. Some antibacterials come with worrisome silver lining. Chicago Tribune, 16

402 Feb. Available from: http://articles.chicagotribune.com/2014-02-16/health/ct-nanosilver-

403 met-20140216_1_consumer-products-other-antibiotic-drugs-germs

404 Donner E, Scheckel K, Sekine R, Popelka-Filcoff RS, Bennett JW, Brunetti G, et al. 2015. Non-

405 labile silver species in biosolids remain stable throughout 50 years of weathering and 406 ageing. Environ Pollut 205: 78-86.

407 Eckhardt S, Brunetto PS, Gagnon J, Priebe M, Giese B, Fromm KM. 2013. Nanobio silver: its 408 interactions with peptides and bacteria, and its uses in medicine. Chem Rev 113: 4708$409 \quad 4754$.

410 Faunce T, Watal A. 2010. Nanosilver and global public health: international regulatory issues.

$411 \quad$ Nanomedicine 5: 617-632.

412 Feng QL, Wu J, Chen GQ, Cui FZ, Kim TN, Kim JO. 2000. A mechanistic study of the

413 antibacterial effect of silver ions on Escherichia coli and Staphylococcus aureus. J Biomed

$414 \quad$ Mater Res 52: 662-668.

415 Ge L, Li Q, Wang M, Ouyang J, Li X, Xing MMQ. 2014. Nanosilver particles in medical

416 applications: synthesis, performance, and Toxicity. Int J Nanomed 9: 2399-2407.

417 
418 Grigor'eva A, Saranina I, Tikunova N, Safonov A, Timoshenko N, Rebrov A, et al. 2013. Fine

419 mechanisms of the interaction of silver nanoparticles with the cells of Salmonella

420 typhimurium and Staphylococcus aureus. Biometals 26: 479-488.

421 Gunawan C, Teoh WY, Marquis CP, Lifia J, Amal R. 2009. Reversible antimicrobial 422 photoswitching in nanosilver. Small 5: 341-344.

423 Gunawan C, Teoh WY, Marquis CP, Amal R. 2011. Cytotoxicity origin of copper(II) oxide 424 nanoparticles: comparative studies with micron-sized particles, leachate, and metal Salts. $425 \quad$ ACS Nano 5: 7214-7225.

426 Gunawan C, Teoh WY, Ricardo, Marquis CP, Amal R. 2013a. Zinc oxide nanoparticles induce 427 428 429 cell filamentation in Escherichia coli. Part Part Syst Charact 30: 375-380.

Gunawan C, Teoh WY, Marquis CP, Amal R. 2013b. Induced adaptation of Bacillus sp. to antimicrobial nanosilver. Small 9: 3554-3560.

Gunawan C, Marquis CP, Amal R, Sotiriou GA, Rice SA, Harry EJ. 2017. Widespread and indiscriminate nanosilver use: genuine potential for microbial resistance. ACS Nano 11: $3438-3445$.

Hajipour MJ, Fromm KM, Ashkarran AA, Jimenez de Aberasturi D, de Larramendi IR, Rojo T, et al. 2012. Antibacterial properties of nanoparticles. Trends Biotechnol 30: 499-511.

Hwang ET, Lee JH, Chae YJ, Kim YS, Kim BC, Sang BI, et al. 2008. Analysis of the toxic mode of action of silver nanoparticles using stress-specific bioluminescent bacteria. Small 4: $746-750$.

Imlay J, Chin S, Linn S. 1988. Toxic DNA damage by hydrogen peroxide through the Fenton reaction in vitro and in vivo. Science 240: 640-642.

Imlay JA. 2003. Pathways of oxidative damage. Annu Rev Microbiol 57: 395-418.

Ivask A, Elbadawy A, Kaweeteerawat C, Boren D, Fischer H, Ji Z, et al. 2014. Toxicity mechanisms in Escherichia coli vary for silver nanoparticles and differ from ionic silver. ACS Nano 8: 374-386. 
444 Kohanski MA, Dwyer DJ, Hayete B, Lawrence CA, Collins JJ. 2007. A common mechanism of $445 \quad$ cellular death induced by bactericidal antibiotics. Cell 130: 797-810.

446 Lemire JA, Harrison JJ, Turner RJ. 2013. Antimicrobial activity of metals: mechanisms, 447 molecular targets and applications. Nat Rev Microbiol 11: 371-384.

448 Levard C, Mitra S, Yang T, Jew AD, Badireddy AR, Lowry GV, et al. 2013. Effect of chloride 449 on the dissolution rate of silver nanoparticles and toxicity to E. coli. Environ Sci Technol $450 \quad 47: 5738-5745$.

451 Li WR, Xie XB, Shi QS, Zeng HY, Ou-Yang YS, Chen YB. 2010. Antibacterial activity and 452 mechanism of silver nanoparticles on Escherichia coli. Appl Microbiol Biotechnol 85: $453 \quad 1115-1122$.

454 Li WR, Xie XB, Shi QS, Duan SS, Ou-Yang YS, Chen YB. 2011. Antibacterial effect of silver 455 nanoparticles on Staphylococcus aureus. Biometals 24: 135-141.

456 Liu J, Wang Z, Liu FD, Kane AB, Hurt RH. 2012. Chemical transformations of nanosilver in 457 biological environments. ACS Nano 6: 9887-9899.

458 Luoma SN, 2008. Silver nanotechnologies and the environment: old problems or new 459 challenges? The PEW Charitable Trusts. Available from: $460 \quad$ https://www.nanotechproject.org/process/assets/files/7036/nano_pen_15 final.pdf $461 \quad$ [Accessed 11 December 2016]

462 Mirzajani F, Ghassempour A, Aliahmadi A, Esmaeili MA. 2011. Antibacterial effect of silver 463 nanoparticles on Staphylococcus aureus. Res Microbiol 162: 542-549.

464 Morones JR, Elechiguerra JL, Camacho A, Holt K, Kouri JB, Ramírez JT, et al. 2005. The 465 bactericidal effect of silver nanoparticles. Nanotechnology 16: 2346-2353.

466 Mulley G, Jenkins ATA, Waterfield NR. 2014. Inactivation of the antibacterial and cytotoxic 467 properties of silver ions by biologically relevant compounds. PLoS One 9: e94409. 
468 Pal S, Tak YK, Song JM. 2007. Does the antibacterial activity of silver nanoparticles depend on 469 the shape of the nanoparticle? A study of the Gram-negative bacterium Escherichia coli. Appl Environ Microbiol 73: 1712-1720.

471 Percival SL, Bowler PG, Russell D. 2005. Bacterial resistance to silver in wound care. J Hosp $472 \quad$ Infect 60: 1-7.

473 Quadros ME, Pierson R, Tulve NS, Willis R, Rogers K, Thomas TA, et al. 2013. Release of 474 silver from nanotechnology-based consumer products for children. Environ Sci Technol $475 \quad 47: 8894-8901$.

476 Reidy B, Haase A, Luch A, Dawson KA, Lynch I. 2013. Mechanisms of silver nanoparticle 477 release, transformation and toxicity: a critical review of current knowledge and 478 recommendations for future studies and applications. Materials 6: 2295-2350.

Silver S. 2003. Bacterial silver resistance: molecular biology and uses and misuses of silver 480 compounds. FEMS Microbiol Rev 27: 341-353.

481 Sintubin L, De Gusseme B, Van der Meeren P, Pycke BFG, Verstraete W, Boon N. 2011. The 482 antibacterial activity of biogenic silver and its mode of action. Appl Microbiol Biotechnol 483 vesicles of Enterococcus hirae. J Biol Chem 270: 9217-9221.

Sondi I, Salopek-Sondi B. 2004. Silver nanoparticles as antimicrobial agent: a case study on $E$. $487 \quad$ coli as a model for Gram-negative bacteria. J Colloid Interface Sci 275: 177-182.

488 Sotiriou GA, Pratsinis SE. 2010.Antibacterial activity of nanosilver ions and particles. Environ $489 \quad$ Sci Technol 44: 5649-5654.

490 Sotiriou GA, Meyer A, Knijnenburg JTN, Panke S, Pratsinis SE. 2012. Quantifying the origin of 491 released Ag+ ions from nanosilver. Langmuir 28: 15929-15936. 
492 Trop M, Novak M, Rodl S, Hellbom B, Kroell W, Goessler W. 2006. Silver-coated dressing

493 Acticoat caused raised liver enzymes and argyria-like symptoms in burn patient. J Trauma-

494 Injury Infect Crit Care 60: 648-652.

495 Xiu ZM, Zhang QB, Puppala HL, Colvin VL, Alvarez PJJ. 2012. Negligible particle-specific

496 antibacterial activity of silver nanoparticles. Nano Lett 12: 4271-4275.

497 Xu FF, Imlay JA. 2012. Silver(I), mercury(II), cadmium(II), and zinc(II) target exposed enzymic

498 iron-sulfur clusters when they toxify Escherichia coli. Appl Environ Microbiol 78: 3614-

$499 \quad 3621$.

500 Consumer Products Inventory - Project on Emerging Nanotechnologies. Available from:

501 http://www.nanotechproject.org/cpi [accessed 1 March 2017].

502

503 Supplementary material is available: Supplementary Figure S1, S2 and S3.

\section{$505 \quad$ Figure captions}

506 Figure 1. Bacterial growth in the presence of Ag NPs, Ag NPs leachate, silver salt and leaching 507 of Ag NPs. (a) Growth of B. subtilis (6 h) relative to cell-only control upon exposure to Ag NPs

$508\left(3,6,8,10 \mathrm{mg} \mathrm{Ag} \mathrm{L}^{-1}\right), \mathrm{Ag}$ leachate from $\mathrm{NPs}$ and $\mathrm{AgNO}_{3}$ as a function of soluble silver

509 detected in the bacterial exposure systems (the growth studies were performed in LB medium).

510 (b) Growth profiles of the bacteria in the presence of $10 \mathrm{mg} \mathrm{Ag} \mathrm{L}^{-1} \mathrm{NPs}$ (4 ppm Ag leached into

511 medium at equilibrium), 4 ppm Ag leachate from NPs and 4 ppm Ag from $\mathrm{AgNO}_{3}$. Also shown

512 is the cell-only control growth profile (dashed line). The growth in the presence of Ag was

513 normalised to the extent of growth of the control (in colony forming units, cfu). (c) The

514 corresponding equilibrium leaching of Ag NPs in the bacterial exposure systems, shown in the

515 inset is the leaching profile for $10 \mathrm{mg} \mathrm{Ag} \mathrm{L}^{-1} \mathrm{NPs}$. Each data point in (a), (b), (c) is the average

516 of triplicate experiments with error bars representing the maximum and minimum values

517 detected. The growth studies were performed under dark conditions to render the $\mathrm{TiO}_{2}$ support 
518 photocatalytically inactive and the benign effect of the $\mathrm{TiO}_{2}$ support on $B$. subtilis growth had

519 been confirmed(Gunawan et al. 2013b). The growth studies were reproduced on different days 520 with unique bacterial inoculum and particle preparations.

521

Figure 2. Detection of cellular reactive oxygen species (ROS, $\mathrm{H}_{2} \mathrm{DCFDA}$ staining, green cells) and cell death (PI staining, red cells) of B. subtilis over its growth course: (a) cell-only control and (b) in the presence of $10 \mathrm{mg} \mathrm{Ag} \mathrm{L}^{-1} \mathrm{NPs}$. All stained samples were imaged at comparable cell concentrations (scale bars $=50 \mu \mathrm{m})$.

Figure 3. Detection of cellular reactive oxygen species (ROS, $\mathrm{H}_{2}$ DCFDA staining, green cells) and cell death (PI staining, red cells) of B. subtilis over its growth course, in the presence of: (a) 4 ppm Ag leachate from NPs (equivalent leachate to $10 \mathrm{mg} \mathrm{Ag} \mathrm{L}^{-1} \mathrm{NPs}$ exposure), (b) $4 \mathrm{ppm} \mathrm{Ag}$ from $\mathrm{AgNO}_{3}$, (c) $8.3 \mathrm{ppm} \mathrm{Ag} \mathrm{leachate} \mathrm{from} \mathrm{NPs} \mathrm{and} \mathrm{(d)} 8.3 \mathrm{ppm} \mathrm{Ag} \mathrm{from} \mathrm{AgNO}_{3}$. All stained samples were imaged at comparable cell concentrations (scale bars $=50 \mu \mathrm{m}$ ).

533 Figure 4. (a) Dynamic stimulation of cellular ROS in B. subtilis measured by $\mathrm{H}_{2}$ DCFDA assay 534 over its growth course $(5,30 \mathrm{~min}$ and $1,3,4.5,6 \mathrm{~h})$ upon exposure to $10 \mathrm{mg} \mathrm{Ag} \mathrm{L}^{-1} \mathrm{NPs}(4 \mathrm{ppm}$ 535 Ag leached into medium at equilibrium), 4 ppm Ag leachate from NPs and $4 \mathrm{ppm} \mathrm{Ag} \mathrm{from}$ $536 \mathrm{AgNO}_{3}$. The detected cellular ROS was normalised to the basal ROS levels of the cell-only 537 control growth. Shown in the inset is cellular ROS detected in the presence of $8.3 \mathrm{ppm} \mathrm{Ag}$ 538 leachate from NPs and $8.3 \mathrm{ppm} \mathrm{Ag}$ from $\mathrm{AgNO}_{3}$. (b) The corresponding dynamic cell death 539 detection probed by PI staining of $B$. subtilis throughout its growth course. Also shown is the 540 fraction of dead cells detected for the cell-only control. Statistical analysis of the data was 541 performed with one-way ANOVA followed by Dunnett's posthoc analysis in Prism (GraphPad)

542 (Figure S3). The experiments in (a) and (b) were reproduced on different days with unique 543 bacterial inoculum and particle preparations. (c) Leaching profile of $10 \mathrm{mg} \mathrm{Ag} \mathrm{L}^{-1} \mathrm{NPs}$ in cell- 
544 free individual components of the Luria Bertani (LB) culture medium $\left(5 \mathrm{~g} \mathrm{~L}^{-1} \mathrm{NaCl}, 5 \mathrm{~g} \mathrm{~L}^{-1}\right.$ yeast 545 extract, $10 \mathrm{~g} \mathrm{~L}^{-1}$ tryptone dissolved in deionized water). Each data point in (a), (b), (c) is the 546 average of triplicate batches with the error bars representing the maximum and minimum. 